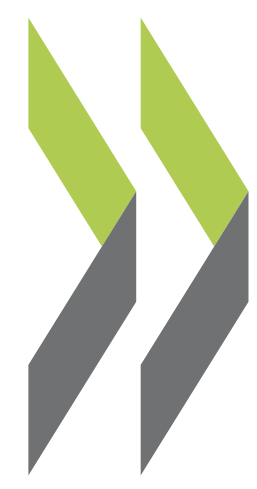

OECD Regional Development Working Papers 2013/19

The Case of Helsinki-Tallinn (Finland-Estonia) - Regions and Innovation: Collaborating Across Borders

\section{Claire Nauwelaers,}

Karen Maguire,

Giulia Ajmone Marsan 


\section{OECD REGIONAL DEVELOPMENT WORKING PAPERS}

This series is designed to make available to a wider readership selected studies on regional development issues prepared for use within the OECD. Authorship is usually collective, but principal authors are named. The papers are generally available only in their original language English or French with a summary in the other if available.

The opinions expressed in these papers are the sole responsibility of the author(s) and do not necessarily reflect those of the OECD or the governments of its member countries.

Comment on the series is welcome, and should be sent to either gov.contact@oecd.org or the Public Governance and Territorial Development Directorate, 2, rue André Pascal, 75775 PARIS CEDEX 16, France.

OECD Regional Development Working Papers are published on http://www.oecd.org/gov/regional/workingpapers

Applications for permission to reproduce or translate all or part of this material should be made to: OECD Publishing, rights@oecd.org or by fax 33145249930.

(C) OECD 2013 


\begin{abstract}
Estonia and Finland have centuries of collaboration, mainly between the capital areas of Tallinn and Helsinki that currently account for 2 million inhabitants and USD 76 billion in economic output. The entry of Estonia into the European Union and, since the mid-2000s, a two-hour ferry trip, have both facilitated flows of people and merchandise across the Gulf of Finland. The different levels of development between Helsinki and Tallinn result in many asymmetric flows (workers to Helsinki, tourists to Tallinn). Beyond infrastructure and labour market issues, there are interesting opportunities for joint innovation policy efforts given their shared strengths such as in ICT, a dynamic start-up environment and technologically sophisticated public services. Cross-border collaboration can help build an "entrepreneurial knowledge region" brand. This case study is part of the project Regions and Innovation: Collaborating Across Borders. A summary of this working paper appears in a report of the same name.
\end{abstract}

JEL classification: R11, R58, O14, O18, O38, L52, L53

Keywords: regional development, regional growth, innovation, regional innovation, regional innovation strategy, science and technology, cross-border, Finland, Estonia, Helsinki, Tallinn 


\section{ACKNOWLEDGEMENTS}

This case study is part of the OECD project Regions and Innovation: Collaborating Across Borders. It is based on a background report prepared by the Helsinki-Tallinn Euregio, as well as additional research and a mission to the cross-border area from 9-11 April 2013. Peer reviewers for this mission were from InterTradeIreland, Eoin Magennis and Bernadette McGahon. This case study was drafted by Claire Nauwelaers (consultant in STI policy) and Karen Maguire (OECD Secretariat) with additional support from Giulia Ajmone Marsan (OECD Secretariat). The team thanks those who participated in the mission interviews, the peer reviewers, and, from the Helsinki-Tallinn cross-border area, Merle Krigul and Katri-Liis Lepik (Helsinki-Tallinn Euregio NPA) and Jasmine Etelämäki (City of Helsinki). 


\section{TABLE OF CONTENTS}

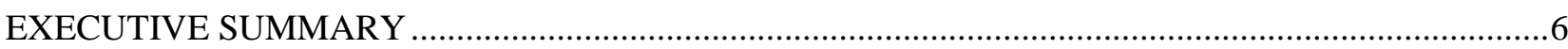

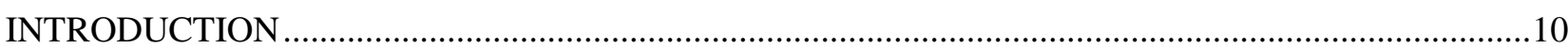

CHAPTER 1 THE HELSINKI-TALLINN CROSS-BORDER AREA AS A FUNCTIONAL REGION ..10

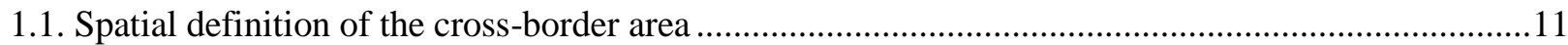

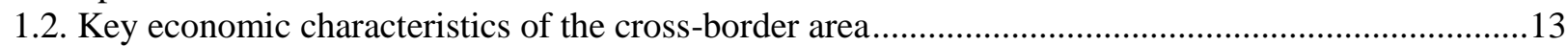

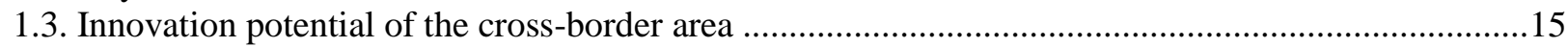

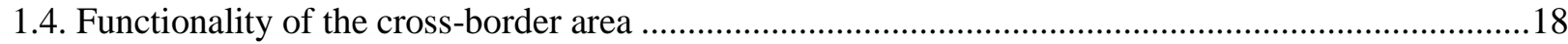

CHAPTER 2 DRIVING FORCE AND KEY ACTORS FOR THE HELSINKI-TALLINN CROSS-

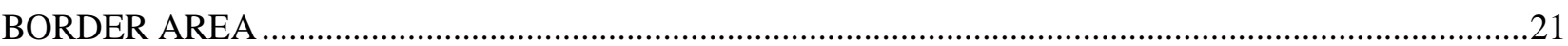

2.1. Rationale for the establishment of the cross-border area ..............................................................21

2.2. Role of key actors in cross-border area establishment and evolution ..............................................23

2.3. Barriers for cross-border co-operation linked to actors .............................................................23

CHAPTER 3 GOVERNANCE OF THE HELSINKI-TALLINN CROSS-BORDER AREA ...................25

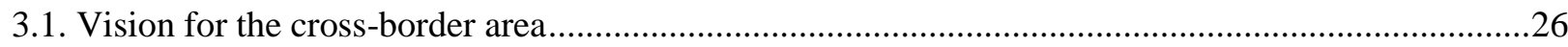

3.2. Institutionalisation and multi-level governance of cross-border co-operation....................................26

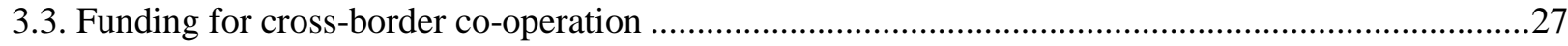

3.4. Barriers for cross-border co-operation linked to governance and funding issues ..............................28

CHAPTER 4 HELSINKI-TALLINN CROSS-BORDER INNOVATION POLICY MIX ….....................28

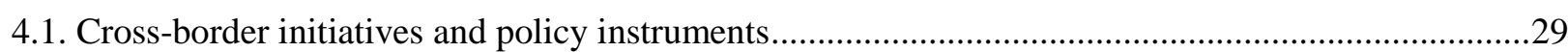

4.2. Untapped potential for promoting cross-border innovation synergies...........................................32

4.3. Relevance and effectiveness of the policy mix for cross-border co-operation .................................37

CHAPTER 5 RECOMMENDATIONS FOR CROSS-BORDER INNOVATION IN HELSINKI-

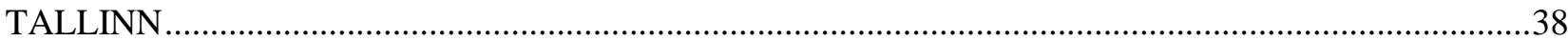

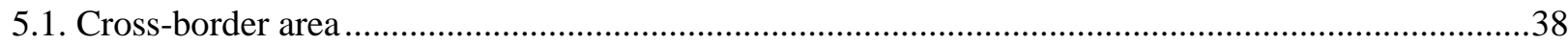

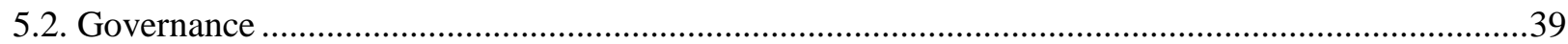

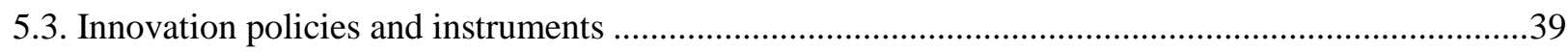

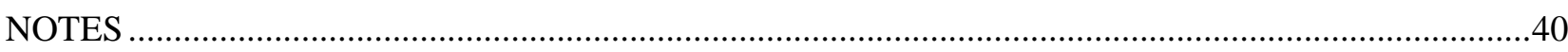

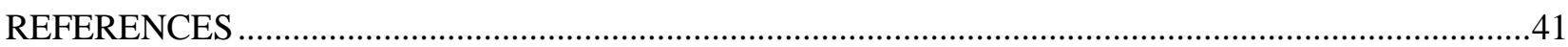

\section{Tables}

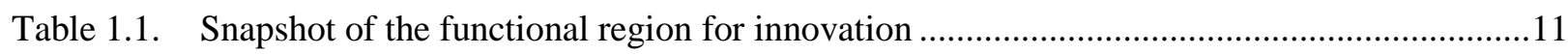

Table 1.2. Socio-economic overview of the cross-border area.......................................................13

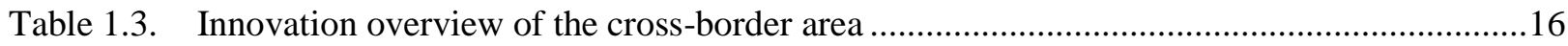

Table 2.1 Snapshot of the rationale and relevance for cross-border collaboration................................21

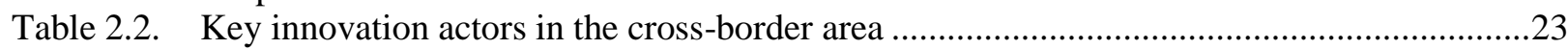

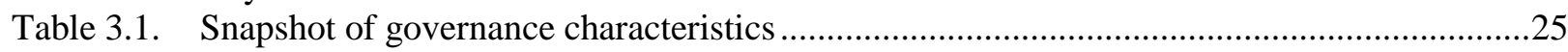

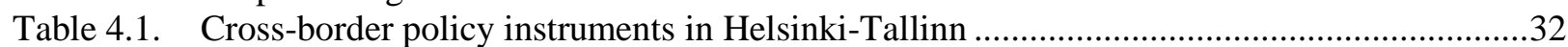

Table 4.2. Snapshot of the innovation policy approach......................................................................37 


\section{Figures}

Figure 1.1. Helsinki-Tallinn cross-border region from a micro-perspective .....................................12

Figure 1.2. Helsinki-Tallinn cross-border region from a macro-perspective.........................................12

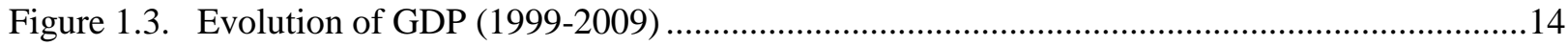

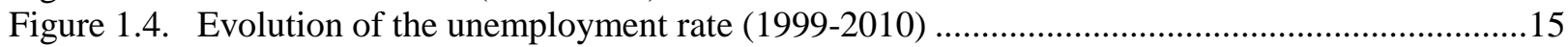

Figure 1.5. Evolution of the R\&D expenditures rate (1999-2011) ......................................................16

Figure 4.1. The Estonian information system and the X-Road data exchange layer ..............................34

\section{Boxes}

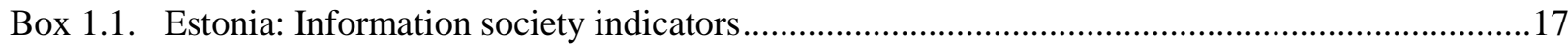

Box 1.2. Cross-border flows of cargo, tourists and workers in Helsinki-Tallinn ..................................17

Box 1.3. Technopolis: A Finnish cross-border company in business support ......................................18

Box 1.4. Examples of bilateral and multilateral research co-operation between Estonia and Finland ....19

Box 2.1. Helsinki-Tallinn Transport and Planning Scenarios..............................................................22

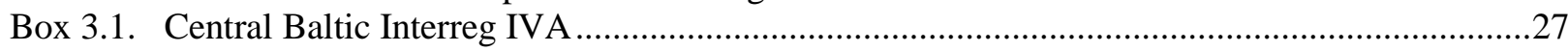

Box 4.1. Examples of cross-border incubator collaboration and start-up support ..................................29

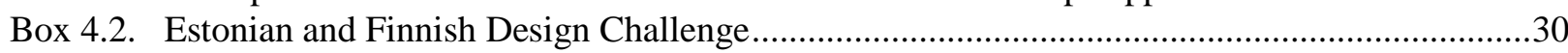

Box 4.3. The X-Road: Data exchange layer from Estonia to be adopted in Finland ..............................33

Box 4.4. Wise men reports on Finnish-Estonian co-operation: Recommendations in the

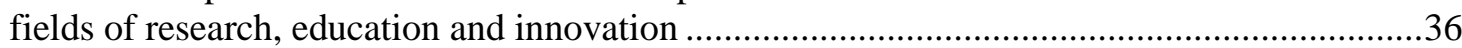


EXECUTIVE SUMMARY

Strengths, weaknesses, opportunities and threats for cross-border innovation policy

\begin{tabular}{|c|c|}
\hline Strengths/assets & Weaknesses/barriers \\
\hline $\begin{array}{l}\text { - Strong economic, political and cultural ties } \\
\text { Increasing degree of cross-border economic } \\
\text { integration through mobility and trade } \\
\text { Joint efforts for twin city and broader regional } \\
\text { efforts (for example the current Helsinki-Tallinn } \\
\text { Euregio) } \\
\text { Support organisations working on both sides of } \\
\text { the border } \\
\text { Proximity in innovation policy frameworks } \\
\text { Entrepreneurial culture and cross-border initiatives } \\
\text { in entrepreneurship } \\
\text { Complementary expertise in ICT applications and, } \\
\text { particularly in Estonia, strengths in public } \\
\text { e-services } \\
\text { Innovation culture that goes beyond technology } \\
\text { (Nordic design, living labs, the Aalto model, etc.) } \\
\text { Improving geographic accessibility } \\
\text { Both countries have the same currency and EU } \\
\text { membership }\end{array}$ & $\begin{array}{l}\text { Unbalanced level of economic and innovation } \\
\text { performance between the two sides } \\
\text { Unbalanced trade and mobility linkages (workers } \\
\text { to Finland, tourists to Estonia) } \\
\text { Insufficient knowledge of actors and assets on the } \\
\text { other side of the border } \\
\text { Differences in public administration culture } \\
\text { Low level of legitimacy and political support of } \\
\text { Euregio, risk of losing co-operation momentum } \\
\text { Knowledge-based development a core element of } \\
\text { the Helsinki-Tallinn Euregio strategy, but less so } \\
\text { with respect to the overall co-operation activity } \\
\text { Constellation of cross-border projects but no } \\
\text { overall strategy for innovation support }\end{array}$ \\
\hline Opportunities & Threats \\
\hline $\begin{array}{l}\text { Proximity to the Russian Federation and } \\
\text { increasing integration within the Baltic Sea region } \\
\text { (including the Rail Baltic EU project) } \\
\text { Building on Finnish-Estonia national level } \\
\text { co-operation efforts } \\
\text { Increased global co-operation through } \\
\text { Finnish-Estonian synergies in innovation strengths } \\
\text { Branding and positioning the cross-border area as } \\
\text { a "start-up"/e-service/open data region in a global } \\
\text { context }\end{array}$ & $\begin{array}{l}\text { Less global visibility relative to other Nordic } \\
\text { innovation hubs } \\
\text { Helsinki-Tallinn as a mere corridor in the Baltic, } \\
\text { with few economic spillovers } \\
\text { Brain drain from both capital cities out of the } \\
\text { cross-border area to other globally competitive hot } \\
\text { spots }\end{array}$ \\
\hline
\end{tabular}

The cross-border area of Helsinki-Tallinn has an opportunity to evolve from a price-driven model towards a knowledge-driven one for an increasingly functional economic/innovation area. A reasonable degree of physical and social proximity exists between the two city-regions, which provides a favourable backdrop against which to exploit this potential. Developing and branding the area as an entrepreneurial hotspot for innovation is an untapped opportunity. The current objective of developing Helsinki-Tallinn as a logistics hub in a wider Baltic Sea context should be complemented by efforts to build on the proximate diversity in innovation assets throughout the cross-border area. Greater critical mass and the unique combination of activities and competences on both sides of the border can lead to the development of exportable innovative products and services with an international competitive edge, such as ICT applications and e-services.

\section{The profile and relevance of the Helsinki-Tallinn cross-border area for innovation}

The twin-city region of Helsinki-Tallinn includes the capital regions of Finland and Estonia, separated by the 65 kilometre-wide Gulf of Finland. The trade ties and mobility flows between the two countries have grown in the last few years, triggered by Estonian accession to the EU and the adoption of 
the euro by both countries. The cross-border area is one piece in the larger puzzle of the Baltic Sea region. The definition of the cross-border region could extend from Tallinn to all of Estonia for innovation given: the small size of the country; the ability to influence national policy; and because the second city of Estonia, Tartu, has long-standing scientific ties with the Helsinki area.

Helsinki-Tallinn is an asymmetric area in terms of size and economic performance, but Estonia is catching up. Between 1999 and 2009, Estonia had an average annual growth rate of around 5\%, higher than the average OECD rate of $1.4 \%$. Estonia is one of the leading countries in Central and Eastern Europe with respect to foreign direct investment (FDI) per capita. The stock of total FDI in 2012 corresponded to EUR 14.3 billion. Half of these investments came from Sweden and Finland. ${ }^{1}$ However, the economic performance gap with Finland remains wide (the GDP per capita of the Tallinn area is $60 \%$ of that for Helsinki). Cost differences between the two economies remain significant. Many Finnish companies invest in Estonia to take advantage of cost differentials. Estonian investments in Finland are of much lower magnitude. Mobility trends also reflect this asymmetry, as workers cross the border from Estonia to Finland to benefit from higher wages. Finns travel to Estonia mainly for tourism. Nevertheless, crossborder accessibility is an issue. Connectivity barriers prevent Helsinki-Tallinn from reaching its full potential as a functional region.

There is a clear potential to exploit complementarities in advanced ICT applications across the area, as well as science co-operation. In Estonia, the societal use of ICT is well developed, in the form of a variety of innovative mobile and e-applications. Finland could build on these advances to develop innovative businesses, as Estonia is a test bed for e-services. The strong science and technology (S\&T) capacity in Finland matches well with entrepreneurship dynamics, especially in ICT, on the Estonian side. Public R\&D co-operation is mostly multilateral (rather than bilateral between the two countries only) and involves the University of Tartu. Cross-border student flows are rising, but are somewhat higher from Estonia to Finland. Cultural differences are present, but they are explicitly acknowledged and often seen as opportunities.

\section{Driving force and key actors for the Helsinki-Tallinn cross-border area}

The main rationale for establishing a Helsinki-Tallinn cross-border area is to address the challenges associated with increased cross-border mobility of freight and people. The improvement of transport infrastructure within, around and between the two capital regions is the primary focus of public sector attention. This concerns both local linkages within the cross-border area and the role of the area as a hub in broader transport flows within the Baltic Sea region.

Overcoming peripherality, through greater critical mass, is another important objective. Policy efforts to take advantage of complementarities in the cross-border area do not target knowledge assets but rather a division of labour according to price differentials. While the idea of science twin-cities has been raised since the early times of cross-border co-operation, it has not yet been operationalized. The two Wise Men reports on Finnish-Estonian co-operation from 2003 and 2008 provided several recommendations pertaining to the development of cross-border research and education. Joint branding is another opportunity, but not one currently as high on the collaboration agenda.

There are several barriers to cross-border co-operation. Major firms and higher education institutions tend to view co-operation opportunities on a broader international scale rather than consider nearby cross-border opportunities. Public funding sources, such as the EU Framework Programme, encourage multilateral over bilateral collaboration. The current use of EU Structural Funds on both sides of the gulf only encourages local activities. The lack of a clear identification of collaboration potential is another barrier for firms and other actors to enter into cross-border partnerships. 


\section{Governance of the Helsinki-Tallinn cross-border area}

Cross-border co-operation is currently institutionalised through a co-ordination body, HelsinkiTallinn Euregio NPA, which is a non-profit association of several public authorities. The Euregio Secretariat provides some technical assistance behind the scenes, but lacks the recognition of many leading public and private actors. The governance of cross-border activity only involves public actors, with weak participation of innovation actors. Euregio has been quite active in generating and collecting data on crossborder flows of freight, goods and people as part of the latest project H-TTransplan; data which are useful to monitor the level of integration of the area. However, data on knowledge potential and flows are less available, limiting awareness and the development of cross-border innovation policies and programmes.

National and regional innovation policies do not explicitly incorporate the goal of fostering cross-border co-operation in innovation, and national policy instruments do not allow cross-border funding. Aligning programmes across borders (through joint calls with separate funding flows) is also not practiced. Public funding for cross-border co-operation in innovation is mainly provided by European Territorial Co-operation (Interreg) funds through the Southern Finland-Estonia sub-programme. This funding source, like in other cross-border areas, suffers from a number of deficiencies for financing crossborder activities with a science or innovation focus.

\section{Helsinki-Tallinn cross-border innovation policy mix}

The most significant joint initiatives under the cross-border partnership between HelsinkiTallinn concern transport and infrastructure development, with a few in the field of innovation. Such innovation activities include a number of temporary initiatives aimed at mutual exchanges in entrepreneurial activities. There are currently no joint policies. Most projects are temporary and funded by European Territorial Co-operation programmes to develop mutual knowledge and joint actions in the area of entrepreneurship, particularly related to the ICT sector. Some projects (twin-city of science launched 2004 and the Knowledge Arena programme since 2006) have also promoted contacts between academics for common scientific projects.

Life sciences, ICT and new materials are areas which have been identified as having potential for joint knowledge-based activities. Helsinki and Tallinn are test bed medium-sized cities for advanced smart city applications. Bilateral co-operation agreements exist between universities in the HelsinkiTallinn area. Joint university participation in multilateral $R \& D$ projects is probably more intense than bilateral co-operation. Several types of joint academic activities in education and research could be further explored, with innovation goals in mind. 


\section{Recommendations for cross-border innovation policies in Helsinki-Tallinn}

Cross-border area: Extend the definition of the cross-border area to Helsinki-Estonia, branded as an "entrepreneurial knowledge region"

- Extend the area to include the whole of Estonia.

- Brand the area as an "entrepreneurial technology region".

Governance: Improve governance mechanisms to include a new "innovation" direction, reinforce the co-ordination function and bring in relevant actors

- Involve national governments to raise the profile of cross-border activities.

- Integrate the triple helix of actors in the governance of the cross-border area.

- Further develop the joint work of the two national R\&D and Innovation Councils.

- Underpin cross-border innovation policy efforts with a stronger policy intelligence function that provides the relevant analysis and data.

Innovation policies and instruments: Mainstream cross-border innovation into national programmes and focus on impacts and results in areas of strong expertise

- Mainstream cross-border policies in the work of Enterprise Estonia and Tekes (Finland).

- Focus on results and impacts as a next step from the current co-operation platforms.

- Encourage opportunities in joint development of e-society applications where skills in the cross-border area are particularly strong, among other priorities, for an overall strategy.

- Further develop the collaboration on entrepreneurship between incubators, technology centres, universities and venture capital funds. 


\section{INTRODUCTION}

Finland and Estonia are close neighbours with political and economic relationships. The two countries have experienced centuries of economic and cultural exchanges, which have increased in recent decades thanks to the consecutive accession of the two countries to the European Union (Finland in 1995 and Estonia in 2004). Since regaining independence in 1991, Estonia is keen to develop as a dynamic and vibrant nation, building in part on the success of its neighbour across the gulf to the north. Economic exchanges (trade, work, tourism, education, etc.) between the two countries have grown as barriers have been steadily lowered. Factors supporting greater exchange include: improved transport connections, lowering of border barriers within the EU, and adoption of the common currency, the euro (in 2002 for Finland and 2011 for Estonia). On two recent occasions, once in 2002 and the other in 2007, the two Prime Ministers asked high-level people from the two countries to produce a joint "Wise Men" report on the bilateral collaboration opportunities. These reports have involved wide consultations and pave the way for new forms collaboration between the two countries (Ollila and Jõerüüt, 2003; Blomberg and Okk, 2008).

Finland and Estonia share common challenges and opportunities within a larger Baltic Sea context. As small economies, the two countries are aware that they have to create international linkages to succeed in global competition. Fostering proximity linkages with close neighbours is one way to tackle this challenge. Attracting investment to this part of the Baltic Sea region is a benefit for both countries. The progress in Baltic Sea integration (notably through the establishment of the Rail Baltic Network and energy grid connections) as well as the closeness to Russian markets are additional opportunities that Finland and Estonia share.

The Helsinki-Tallinn Euregio was established in 1999 as a network and as a non-profit association in $\mathbf{2 0 0 3}$ for exchange between the Finnish and Estonian capital regions. The economic situation of the two countries has evolved considerably since the Euregio collaboration began in 1999. Many subjects have been raised in the cross-border partnership, ranging from connections in Europe, identification of joint problems, academic co-operation, improvement of the joint business environment, joint social services and cultural activities, transport infrastructure, etc.

Helsinki-Tallinn co-operation could seek to valorise more the "innovation" dimension to its strategic collaboration. A decade after formally establishing Euregio for cross-border co-operation, it is now time to assess further the potential for developing Helsinki-Tallinn as a knowledge-driven cross-border region. This idea was already included in the political discussions at early stages, and there are some cross-border innovation activities, but the subject has not yet materialised at the core of the overall cross-border efforts of the area, even if Euregio's projects may involve triple helix configurations of public and private actors. 


\section{CHAPTER 1}

\section{THE HELSINKI-TALLINN CROSS-BORDER AREA AS A FUNCTIONAL REGION}

Table 1.1. Snapshot of the functional region for innovation

(Helsinki-Tallinn in bold)

\begin{tabular}{|c|c|c|}
\hline Characteristic & Specification & Comments \\
\hline Region settlement patterns & $\begin{array}{l}\text { Metropolitan area } \\
\text { Network of small and } \\
\text { medium-sized cities } \\
\text { Sparsely populated with } \\
\text { small towns }\end{array}$ & $\begin{array}{l}\text { Helsinki-Tallinn is characterised by the } \\
\text { presence of two medium-sized metropolitan } \\
\text { areas on both sides (Helsinki and Tallinn) that } \\
\text { are also respective national capitals. }\end{array}$ \\
\hline $\begin{array}{l}\text { Internal accessibility and flows } \\
\text { (geographic proximity) }\end{array}$ & $\begin{array}{l}\text { Strong } \\
\text { Moderate } \\
\text { Weak }\end{array}$ & $\begin{array}{l}\text { Helsinki and Tallinn are separated by the } \\
65 \text { kilometre-wide Gulf of Finland. Flight and } \\
\text { fast ferry connections provide linkages between } \\
\text { the two cities. Despite improvements, the time } \\
\text { and cost of crossing the gulf limits integration of } \\
\text { the area. }\end{array}$ \\
\hline $\begin{array}{l}\text { Industrial and knowledge } \\
\text { specialisations } \\
\text { (cognitive proximity) }\end{array}$ & $\begin{array}{l}\text { Similar with } \\
\text { complementarities } \\
\text { Same } \\
\text { Different }\end{array}$ & $\begin{array}{l}\text { The two regions have different economic } \\
\text { structures and levels of development. There } \\
\text { are, however, several areas of common } \\
\text { specialisation, such as for ICT applications. }\end{array}$ \\
\hline $\begin{array}{l}\text { Socio-cultural context } \\
\text { (social proximity) }\end{array}$ & $\begin{array}{l}\text { Very similar } \\
\text { Somewhat similar } \\
\text { Different }\end{array}$ & $\begin{array}{l}\text { Despite cultural and linguistic differences, the } \\
\text { two regions have a long history of exchanges } \\
\text { and a good degree of mutual understanding. }\end{array}$ \\
\hline Innovation system interactions & $\begin{array}{l}\text { Pervasive } \\
\text { Hub-to-hub } \\
\text { On the border }\end{array}$ & $\begin{array}{l}\text { Most innovation interactions take place } \\
\text { between the two urban hubs. They are limited } \\
\text { to a relatively small number of actors. Science } \\
\text { collaboration also includes the University of } \\
\text { Tartu, further south in Estonia. }\end{array}$ \\
\hline $\begin{array}{l}\text { Level of innovation development } \\
\text { across border }\end{array}$ & $\begin{array}{l}\text { Balanced, strong } \\
\text { Balanced, weak } \\
\text { Unbalanced }\end{array}$ & $\begin{array}{l}\text { There is an imbalance between the two sides of } \\
\text { the cross-border area, with Helsinki being a } \\
\text { highly knowledge-intensive hub and Tallinn } \\
\text { displaying lower overall values on most } \\
\text { common innovation-related indicators, although } \\
\text { it is improving fast and internationally } \\
\text { recognised for its excellence in IT and } \\
\text { e-services. }\end{array}$ \\
\hline
\end{tabular}

\subsection{Spatial definition of the cross-border area}

The twin-city cross-border region of Helsinki-Tallinn includes the two capital regions of Finland and Estonia. The formal definition of the Helsinki-Tallinn cross-border area maps to the geographic coverage of the two regions: Uusimaa County in Finland and Harju County in Estonia. Those two regions are partners in the Euregio and correspond to the extended metropolitan areas around the two capitals, which are separated by the 65 kilometre-wide Gulf of Finland (Figure 1.1). They cover the most densely populated regions in their respective countries, as well as where national economic activity is concentrated. The Helsinki region accounts for around $16 \%$ of its national population and 36\% of total Finnish GDP. The Tallinn area represents a proportionately larger national share, $39 \%$ of population and $61 \%$ of Estonia's GDP. $^{2}$ 


\section{Figure 1.1. Helsinki-Tallinn cross-border region from a micro-perspective}
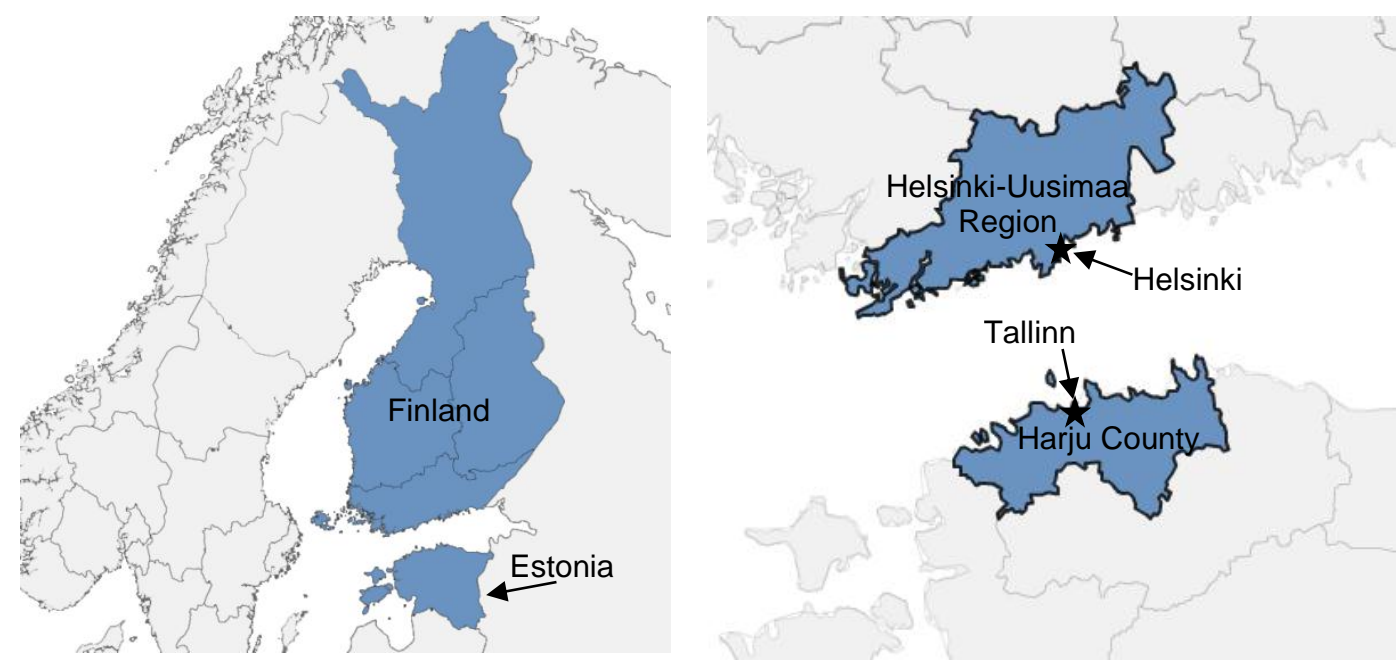

Note: These maps are for illustrative purposes and are without prejudice to the status of or sovereignty over any territory, to the delimitation of international frontiers and boundaries and to the name of any territory, city or area.

Source: OECD (2013), OECD eXplorer, www.oecd.org/gov/regional-policy/oecdexplorer.htm (accessed 15 October 2013).

\section{Figure 1.2. Helsinki-Tallinn cross-border region from a macro-perspective}

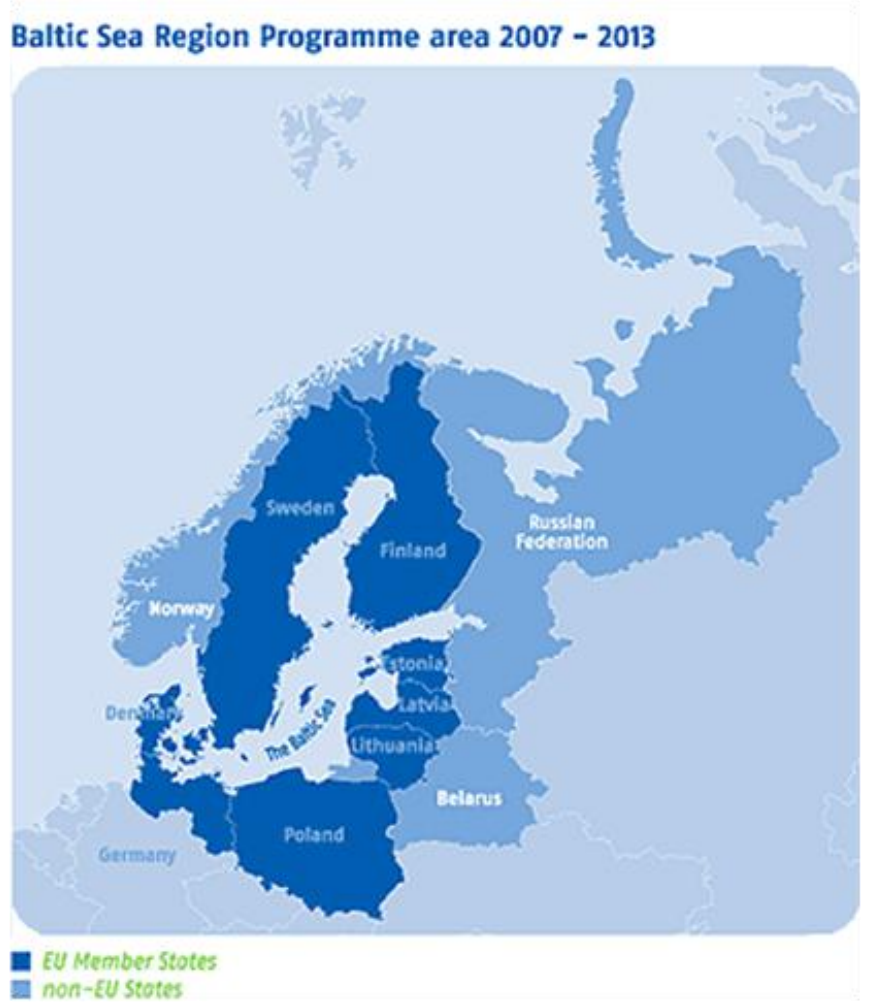

Note: This map is for illustrative purposes and is without prejudice to the status of or sovereignty over any territory, to the delimitation of international frontiers and boundaries and to the name of any territory, city or area.

Source: http://eu.baltic.net. 
Helsinki-Tallinn belongs to the broader Baltic Sea region. From a policy perspective, it is important to note that this cross-border region is one piece in the larger puzzle of the Baltic Sea region, the first EU "macro-region" established in 2009 (Figure 1.2). This geographic situation and the role of the area as a gateway to the Russian Federation both have important implications for the focus of the cross-border strategies, which place an important priority on transport infrastructure development (see Chapter 2).

The definition of the cross-border region could extend to Helsinki-Estonia. While most knowledge-based activities are concentrated in the Estonian capital city, the second city of Estonia, Tartu, has strong ties with Helsinki. ${ }^{3}$ This northern connection is likely to be much more relevant for Estonian innovation actors outside of the capital region, than connections to neighbouring Latvia to the south. Furthermore, from a policy perspective, having the Estonian national government as an active counterpart in cross-border efforts with Southern Finland is an asset, even if the rural areas outside of the urban centres are unlikely to be active in cross-border collaboration activities.

\subsection{Key economic characteristics of the cross-border area}

Helsinki-Tallinn is an asymmetric area (i.e. the two sides are unbalanced) in terms of size and economic performance. With a population of 1.5 million on the Finish side, and 0.5 million on the Estonian side, the bulk of activity is in the north. Estonia is on a fast growth path; however, its economic performance gap with Finland and the EU/OECD average, measured in GDP per capita, remains wide, with GDP per capita of the Tallinn area only 60\% that of the Helsinki region (Table 1.2 and Figure 1.3). Estonia managed to reduce its unemployment rate between 2000 and 2008; however, it more than doubled in the wake of the 2008 economic downturn (Figure 1.4). Accessing the neighbouring Finnish labour market has therefore been recognised as a clear opportunity for the Estonian unemployed labour force.

Table 1.2. Socio-economic overview of the cross-border area

\begin{tabular}{lcc}
\hline \multicolumn{1}{c}{ Variable } & Helsinki (Uusimaa) & Tallinn (Pohja-Eesti) \\
\hline $\mathrm{Km}^{2}$ & 6371 & 4333 \\
Population (2009) & 1405974 & 524938 \\
Population density (inhabitants $\left./ \mathrm{km}^{2}\right)$ & 222 & 121 \\
Main cities (population) & Helsinki (600 000) & Tallinn (405 500) \\
Unemployment rate (2009) & 6.19 & 11.85 \\
GDP per capita, USD PPP, constant prices 2005 (2009) & 42396 & 25364 \\
\hline
\end{tabular}

Note: Uusimaa and Pohja-Eesti are the corresponding TL3 regions including the two metropolitan areas of Helsinki and Tallinn respectively.

Sources: OECD Regional Database, http://dx.doi.org/10.1787/region-data-en and Helsinki-Tallinn Euregio (2013), "Background report for OECD study on cross-border regional innovation policies: Helsinki-Tallinn".

Cost differences are significant between the two economies, and drive cross-border investment from Finland to Estonia and worker flows to Finland. It is estimated that the cost of labour today is two to three times lower in Estonia than it is in Finland (Helsinki-Tallinn Euregio, 2013). This creates a flow of investments driven in large part by these cost differentials, notably through sub-contracting practices from Finnish companies in Estonia and cross-border direct investment. Finnish companies that invest in Estonia do so mostly through acquisitions, to take advantage of the cost differentials. In 2011, 25\% of the FDI stock in Estonia was under Finnish control. ${ }^{4}$ Investments made by Estonian companies in Finland have increased over the last few years. Between 2005 and 2010, the number of Estonian companies in Finland increased by a factor of three. However, investments of Estonian companies in Finland are significantly lower than those made by Finnish companies in Estonia (Uljas, 2012). The liberal business environment in Estonia, including low corporate taxes and less bureaucratic red tape, is also a factor favouring Finnish investments in Estonia. 
Economic specialisations differ but co-operation is frequent. Estonia is specialised (in terms of employment) in the following sectors (by decreasing order of importance): transport and logistics, energy, construction, ICT and business services. The Helsinki metropolitan area is specialised in media (film, TV, publishing, communications), finance/insurance, and information services/software (Helsinki-Tallinn Euregio, 2013). However, the largest employers in Helsinki are in the public sector: social and health, public administration and education. Finland hosts many large companies, with few mid-size companies, while Estonia is mostly a country of small firms (in Finland 52\% of workers are employed in companies with more than 250 employees, whereas in Estonia only 25\% of workers are). Large Finnish companies have increased their practice of using Estonian experts in sectors such as energy and ICT.

Figure 1.3. Evolution of GDP (1999-2009)

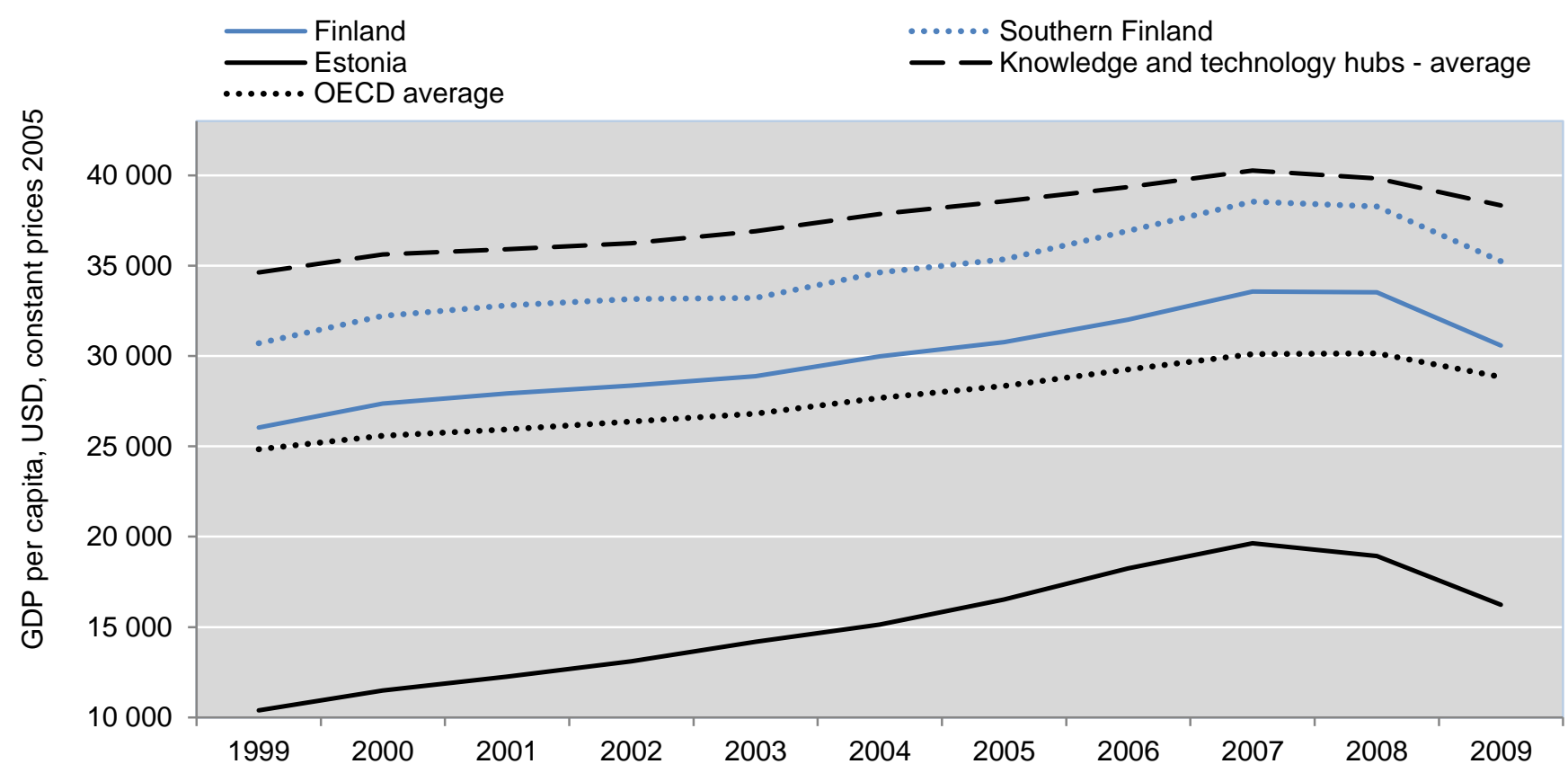

Note: "Knowledge and technology hubs" peer regions average: Southern Finland is a member of this peer group. For a definition of peer regions on the basis of knowledge economy indicators, see Ajmone Marsan and Maguire (2011).

Source: OECD Regional Database, http://dx.doi.org/10.1787/region-data-en. 


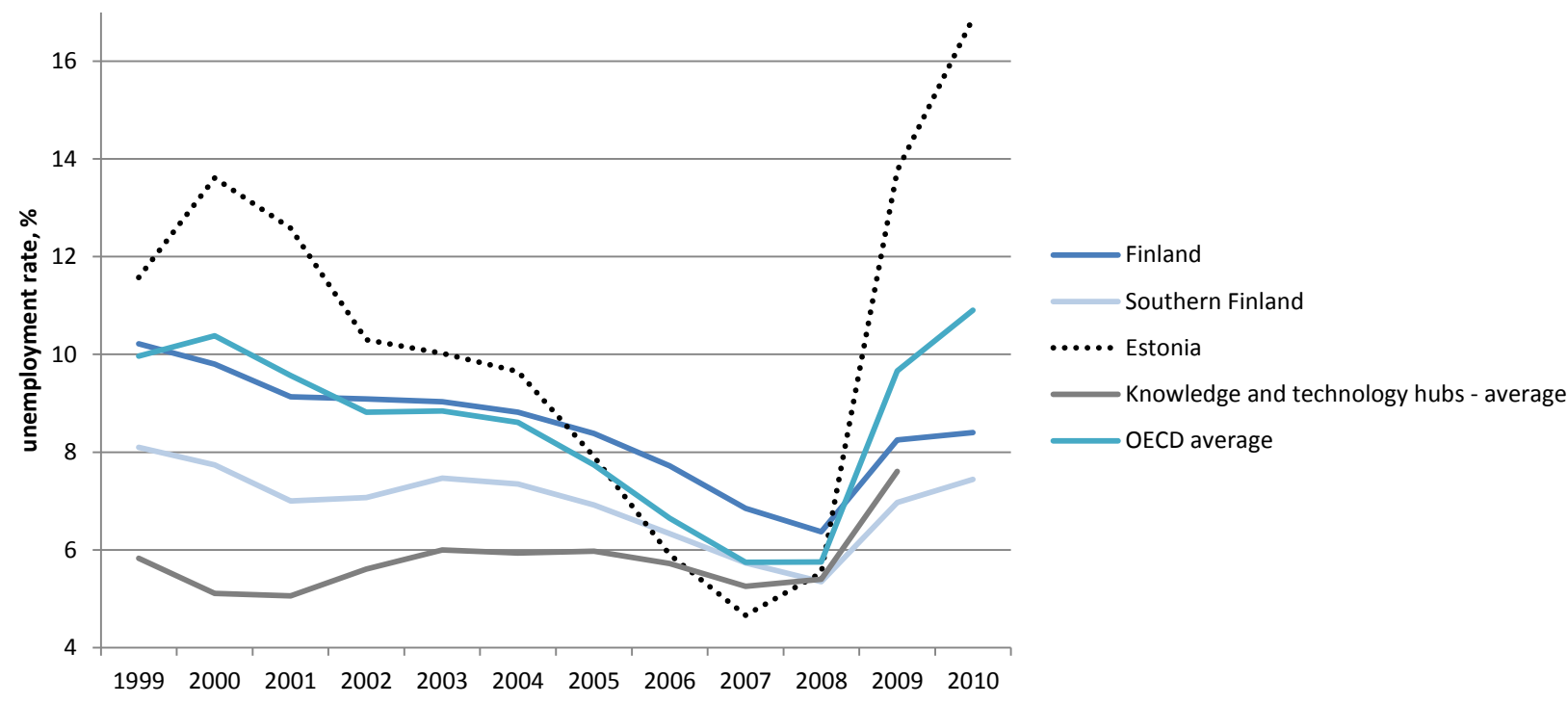

Note: "Knowledge and technology hubs" peer regions average: Southern Finland is member of this peer group. For a definition of peer regions on the basis of knowledge economy indicators, see Ajmone Marsan and Maguire (2011).

Source: OECD Regional Database, http://dx.doi.org/10.1787/region-data-en.

\subsection{Innovation potential of the cross-border area}

Helsinki-Tallinn is an unbalanced area in terms of innovation potential, but Estonia shows signs of catching up. In comparison to other EU member countries, innovation indicators place Estonia in the "innovation follower" category while most of Finland, and Southern Finland in particular, is among the "innovation leaders" group (European Commission, 2012). Estonia displays lower rates of R\&D investments, both in the public and private sectors, and scarce patenting activity (Table 1.3). The share of innovative companies (33.5\%) is high in an EU perspective (31.8\% on average); however, this indicator may be biased by the extremely high level of innovation expenditures in the purchase of equipment and machinery (European Commission, 2012). R\&D activities (intra-muros or external) are less common. These global figures reflect a need to modernise and develop innovation in the many traditional sectors of Estonia, especially outside of the Tallinn growth pole. Looking at trends over time, Estonia displays a remarkable increase in R\&D investments over the last decade, well above the stagnating trend among the EU-27, but remaining well below the high level of Finnish R\&D expenditures (Figure 1.5). 
Table 1.3. Innovation overview of the cross-border area

\begin{tabular}{lccc}
\hline \multicolumn{1}{c}{ Variable } & $\begin{array}{c}\text { Southern } \\
\text { Finland }\end{array}$ & Estonia & $\begin{array}{c}\text { OECD peer } \\
\text { average } \\
\text { knowledge and } \\
\text { technology hubs }\end{array}$ \\
\hline Tertiary educational attainment as a share of labour force (2008) & 39 & -- & 30.8 \\
R\&D personnel (2010) (as a \% of total employment) & 3.6 & $1.7^{2}$ & 2.7 \\
Share of employment in high-tech manufacturing (2008) & 44.5 & -- & 49.2 \\
Share of employment in knowledge-intensive services (2008) & 57.9 & -- & 56.7 \\
Total R\&D expenditure as a share of GDP (2009) & 3.8 & $2.4^{2}$ & 3.9 \\
Business R\&D expenditure as a share of GDP (2009) & 2.6 & $1.5^{2}$ & 2.9 \\
Share of R\&D by the private sector (2009) & 68.4 & 62.5 & 74.3 \\
PCT patents per million inhabitants (average 2008-10) & 342 & 34 & 260 \\
\hline
\end{tabular}

Notes: 1. Only EU regions for R\&D expenditure and personnel variables. 2. Data are for 2011.

Source: OECD (2013) Regional Database, http://dx.doi.org/10.1787/region-data-en; Eurostat; Helsinki-Tallinn Euregio (2013), "Background report for OECD study on cross-border regional innovation policies: Helsinki-Tallinn".

Figure 1.5. Evolution of R\&D expenditures as a share of GDP (1999-2011)

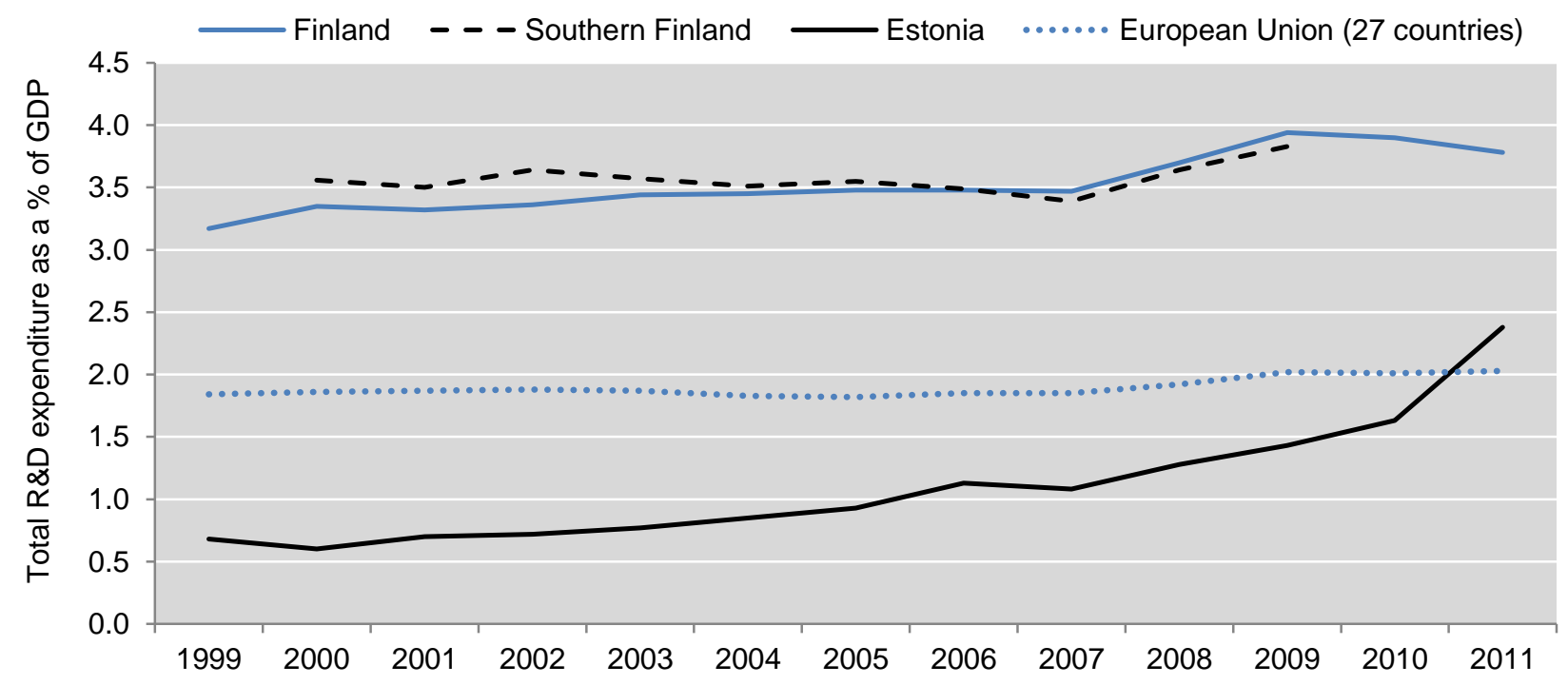

Source: Eurostat and OECD Regional Database, http://dx.doi.org/10.1787/region-data-en.

There is clear potential in exploiting complementarities in advanced ICT applications. In Estonia, the societal use of ICT is well developed, through country-wide diffusion and adoption of ICT and as well as the development of a variety of innovative e- and mobile applications (Box 1.1). Finland could benefit from these advances to further develop innovative businesses, using Estonian actors as a partner and test bed. Combining Estonia's advantage in implementing new uses of ICT with Finland's policy on open public data, for example, is a unique combination that is an asset in international comparison. Generally speaking, the strong S\&T capacity in Finland matches well with strong entrepreneurship dynamics, especially in ICT, on the Estonian side, where the rate of enterprise creation pre-crisis (15.5.\%) was higher than in Finland (12\%) (OECD, 2013). 


\section{Box 1.1. Estonia: Information society indicators}

- $100 \%$ schools IT equipped

- $97 \%$ of businesses use computers

- $76 \%$ of families have a computer; $75 \%$ with broadband connection

- Broadband country wide (3G and 4G network)

- 1129 wifi access points

- Internet access is a social right

- More than $90 \%$ of the population has an electronic ID card

- Every citizen gets an email address from the state

- $99 \%$ of bank transfers are made via the Internet

- $94 \%$ of income tax declarations are made via the Internet (pre-filled, direct access to data)

- $24 \%$ votes via the Internet

- Driver's license can be checked online by police (no need to carry physical copies)

- $95 \%$ of drugs prescriptions are e-prescriptions.

Source: Taavi Kotka, Vice-Chancellery, Ministry of Economy and Communications, "ICT based services and Tiger Leap", OECD mission, 9-11 April 2013.

\section{Box 1.2. Cross-border flows of cargo, tourists and workers in Helsinki-Tallinn}

\section{Cross-border cargo flows}

The cargo Helsinki-Tallinn route has become increasingly important for the traffic of goods between Finland and Estonia as well as internationally. This is witnessed by the constant annual increase (around $10 \%$ in recent years) of cargo volume between the two ports. Moreover, the fast and reliable sea port connections between the two cities have made it possible for service and logistic companies to expand their activities on the other side of the border.

\section{Cross-border flows of tourists}

In 2011, approximately 346000 Estonian residents visited Helsinki-Uusimaa. Their spending in the region was estimated at EUR 66 million. Tourist flows in the opposite direction (from Finland to Tallinn-Harju) were 1.5 million, four times higher. Their total spending was about EUR 266 million. In both directions, $50-60 \%$ of the tourists came from the respective capital region. The tourism flow from Estonia to Finland has quadrupled in ten years while the growth has been smaller in the other direction.

\section{Cross-border flows of workers}

Around $40 \%$ of Estonians travelling to Finland do so for work-related reasons, against $29 \%$ of Finns. The majority of Estonians travelling to Finland for work do so regularly (79\%). Half of work-related travel by Finns to Estonia is for regular commuters $(49 \%)$, and the other half is for more occasional travel for meetings and conferences.

The economic flows connected with cross-border workers are significantly bigger than those of tourism. The gross earnings of people from Tallinn-Harju working in Helsinki-Uusimaa were estimated at about EUR 300-400 million in 2011 (equally split between residents in Finland and commuting workers). Available evidence indicates that most of these jobs concern construction work and healthcare services, and that differences in wage levels play an important role in the attraction of Finland as a labour market for Estonians. Knowledge of Russian language is an asset held by Estonian workers working in the Finnish service sector.

Source: Laakso et al. (2012), Economic Flows Between Helsinki-Uusimaa and Tallinn-Harju Regions, Helsinki-Tallinn Transport and Planning Scenarios Project; Bloomberg, J. and G. Okk (2008), Opportunities for Co-operation between Estonia and Finland 2008, Prime Minister's Publications, Helsinki, 10/2008; Merk, O., O.-P. Hilmola and P. Dubarle (2012), "The competitiveness of global port-cities: The case of Helsinki, Finland", OECD Regional Development Working Papers, No. 2012/08, OECD Publishing, http://dx.doi.org/10.1787/5k92z70x5v7g-en. 


\subsection{Functionality of the cross-border area}

Mobility trends within the Helsinki-Tallinn cross-border area are on the rise but asymmetric, with workers going to Finland and tourists going to Estonia. Available data show that Helsinki and Tallinn are increasingly connected in terms of people flows (Box 1.2). Tourist flows are unbalanced with Helsinki to Tallinn flows being much larger than flows in the other direction. For foreign tourists, notably from Asia, Helsinki-Tallinn is increasingly seen as a joint tourist destination. The reverse imbalance exists for flows of workers, mostly from Tallinn to Helsinki. A large share of these flows are low-skilled workers (in the construction sector, notably), but there are also some high-skilled workers, such as doctors. Public services have been developed to support cross-border mobility of workers given the rise of such flows (EURES, the EU-sponsored support service for trans-border workers). A model of flows built on wage differentials should not prevent the cross-border region from seeking more innovation-driven exchange.

Cross-border trade between Finland and Estonia was triggered by Estonian accession to the EU and the adoption of the euro by both countries. The trade ties between the two countries are strong, especially from an Estonian point of view. Finland is Estonia's largest import partner and second largest export partner. For small Estonian companies, exporting to Finland is a useful first step towards exporting to more challenging markets (in terms of geographic distance and differences in market characteristics) (Helsinki-Tallinn Euregio, 2013).

Cross-border ownership of companies creates strong economic - but few R\&D - linkages between Finland and Estonia. Finnish companies have extended their activities to neighbouring Estonia. Six of the 30 largest companies in Estonia, mostly in the ICT sector, were owned by Finnish companies in 2006, employing 12\% of employees from these large firms in Estonia. However, these Estonian subsidiaries do not specialise in R\&D activities (Laakso et al., 2012). In the first half of 2012, about EUR 3.1 billion worth of direct investment was made from Finland to Estonia, i.e. 23\% of FDI stock in Estonia is under Finnish control. An interesting example is that of the real estate company Technopolis, which owns business parks on both sides of the border (Box 1.3). One reason to establish business in Estonia is the proximity to Russian markets while still being within the EU borders. Fewer Estonian companies have subsidiaries in Finland: Estonia is in 14th place with respect to the turnover from foreign-owned companies in Greater Helsinki (EUR 285 million out of a total of almost EUR 40 billion, and 1038 employees out of a total of 108 219) (Laakso et al., 2012). Company investments from Estonia to Finland are concentrated in construction micro-firms, with little value-added. Cleaning services, beauty treatment, interim job service companies, healthcare, social care, IT services, transport, retail trade, design, and $\mathrm{B} 2 \mathrm{~B}$ services are among the most common sectors for Estonians to set up companies in Finland (mostly in the Helsinki area).

\section{Box 1.3. Technopolis: A Finnish cross-border company in business support}

In 2010, the Finnish publicly traded company Technopolis bought a majority share in the Ülemiste City Technology Park, located next to the Tallinn Airport, and renamed Technopolis Ülemiste. Technopolis Plc is a listed real estate company that specialises in leasing space and providing services. Its core business idea is to combine business support services with modern, flexible, multi-user business environments. There are approximately 22000 people and almost 1400 companies and organisations in Technopolis premises in Finland, the Russian Federation and Estonia. Technopolis PIc's share is listed on NASDAQ OMX Helsinki.

Ülemiste City business campus, also known as Smart Business City, is the most significant cluster of ICT companies in Tallinn, with an excellent existing customer base and high growth potential given its building rights for up to around $150000 \mathrm{~m}^{2}$. The airport has pedestrian access to Technopolis Ülemiste, which houses some 130 companies. There are $46000 \mathrm{~m}^{2}$ of modern office and meeting facilities on the campus. It also features $24000 \mathrm{~m}^{2}$ of industrial and warehouse space. Phase II of Technopolis Ülemiste has begun. Approximately $24000 \mathrm{~m}^{2}$ of office premises will be built.

Source: Helsinki-Tallinn Euregio (2013), "Background report for OECD study on cross-border regional innovation policies: Helsinki-Tallinn". 
Public R\&D co-operation is mostly multilateral rather than bilateral, and involves Tartu. Estonian and Finnish public research actors develop bilateral research co-operation (Box 1.4), but most of this co-operation takes place within wider partnerships, in the context of the EU R\&D framework programme of Nordic and Baltic Sea networks. Exceptions exist, e.g. the joint Estonian-Finnish contribution for the funding of a specific line in large infrastructure such as the MAX IV lab in Sweden, or student and staff exchanges between universities in Southern Finland and Estonia (see Chapter 4). It is worth noting that the University of Tartu (outside of the Helsinki-Tallinn Euregio definition) is a regular partner for Southern Finnish universities. In 2001, it was the most frequent international destination for Finnish teachers and other staff, as well as the most popular Estonian university among Finnish students (Heinonen, 2003).

\section{Box 1.4. Examples of bilateral and multilateral research co-operation between Estonia and Finland}

The Finnish research institutes MTT Agrifood Research Finland, the Finnish Geodetic Institute, the Finnish Food Safety Authority Evira and the Finnish Forest Research Institute Metla have launched or are planning to launch joint projects with Estonian actors. The Finnish Communications Regulatory Authority has worked together with its Estonian counterpart on matters of data security in the information society. The Finnish Meteorological Institute has diverse co-operation projects under way. For example, the electric solar wind sail, a Finnish invention that has received an innovation award, is being developed together with Estonian partners in a European consortium of five countries. The first space trial of the electric sail, or a small satellite named ESTCube-1 built by students at Tartu University and Tallinn University of Technology, was launched in 2013. The Finnish National Institute for Health and Welfare has engaged in long-term co-operation in public health studies, currently in particular in the area of the genetics of national diseases. Co-operation is also on-going in environmental health management and bio-bank creation (e.g. Erasmus) and Nordic programmes (e.g. Nordplus).

The Baltic University Program (BUP) is a network of some 25 universities and other higher education institutions in the Baltic area. Co-ordinated by Uppsala University (Sweden) as part of the activities of the Uppsala Centre for Sustainable Development, BUP programme participants include nine Finnish and three Estonian universities (the Universities of Tallinn and Tartu, and the Tallinn University of Technology).

Source: Helsinki-Tallinn Euregio (2013), "Background report for OECD study on cross-border regional innovation policies: Helsinki-Tallinn".

Cross-border student flows are rising, with somewhat more Estonians going to Finland than the reverse. In 2011, 800 Estonian degree students studied in Finland, compared to 536 Finnish students in Estonia (up from 450 in 2009). For the past ten years, Estonian students have been consistently one of the largest groups of foreign students in Finland. Universities estimate that student mobility between Finland and Estonia will remain approximately at its current levels in the future. The same picture holds for exchange students: in 2011, 74 exchange students from Finnish higher education institutions studied in Estonia while the number of exchanges in the other direction was 139 (CIMO, 2011). Most of the exchanges in higher education are channelled through Erasmus and Nordplus programmes.

Cultural differences are present, but they are explicitly acknowledged and generally seen as opportunities. While Finns and Estonians share many characteristics, they are also different: "Estonia and Finland complement each other - the Finnish deliberateness and planning versus the Estonian readiness to take chances and experiment" (Terk, 2012). Whether these differences hinder or constitute a chance for cross-border exchanges and integration can be debated. The fact that they are acknowledged is, as such, a positive element for further cross-border integration. Both cities are keen to develop cultural events with the aim to attract tourists and residents to each side of the gulf, building on cultural identities. Weak fluency in the neighbouring language is reported as one barrier for further integration, and this is reportedly increasing with the younger generations. English is increasingly used for cross-border communication. Differences in business culture are also reported as a hindrance for co-operation for Estonians active in Finland. $^{5}$ 
Regulations on the Finnish side are experienced as a hurdle to cross-border trade and investment by Estonians. Business surveys reveal that regulatory and administrative barriers are experienced as important hurdles for Estonian economic actors willing to invest or trade in Finland. On the other hand, the frequency of rule changes in Estonia is also a drawback for Finnish investors, albeit within a context of an otherwise liberal and entrepreneur-friendly economic environment. Some reported obstacles from the Estonian perspective are related to the closed Finnish market, where prejudices are still present, long-term planning is required and the labour market heavily regulated (Uljas, 2012). ${ }^{6}$

Cross-border accessibility remains an issue, even if fast ferry connections make it possible to travel between the two cities in an hour and a half to two hours (depending on the time of year). Airline flights are just over half an hour, but require airport transit and check-in times. Helicopter crossings are less frequent than in the past. ${ }^{7}$ The generally accepted definition of a functional region from a labour market perspective usually implies less than a two-hour driving time. Discussions about the possibility of digging a tunnel between the two shores of the Gulf of Finland reflect the importance of infrastructure for increasing integration, albeit there are diverging estimates about the financial viability of such a tunnel. Additionally, barriers are reported in the form of high prices for air and sea connections, and road congestion to reach airports and seaports. These connectivity barriers prevent Helsinki-Tallinn from reaching its full potential as a functional region. 


\section{CHAPTER 2}

\section{DRIVING FORCE AND KEY ACTORS \\ FOR THE HELSINKI-TALLINN CROSS-BORDER AREA}

\subsection{Rationale for the establishment of the cross-border area}

Table 2.1. Snapshot of the rationale and relevance for cross-border collaboration

(Helsinki-Tallinn in bold)

\begin{tabular}{lll}
\hline \multicolumn{1}{c}{ Driver } & \multicolumn{1}{c}{ Explanation } & \multicolumn{1}{c}{$\begin{array}{c}\text { Relevance for } \\
\text { cross-border co-operation }\end{array}$} \\
\hline Economies of scale & $\begin{array}{l}\text { Combine resources for efficiency of investment, larger labour } \\
\text { markets or access to wider business and knowledge networks } \\
\text { to increase critical mass; often used to overcome peripherality }\end{array}$ & $\begin{array}{l}\text { Strong } \\
\text { Moderate } \\
\text { Weak }\end{array}$ \\
& & Not present \\
Political recognition & $\begin{array}{l}\text { Increase the recognition and strengths of areas that are far from } \\
\text { capitals to better negotiate and compete for resources from } \\
\text { higher levels of government }\end{array}$ & $\begin{array}{l}\text { Strong } \\
\text { Moderate }\end{array}$ \\
& & Weak \\
Complementarities & Build on diversity of assets in terms of research, technology and & Sot present \\
& economic base, as well as supply chain linkages & Soderate \\
& & Weak \\
Branding & & Not present \\
& Increase internal recognition of the cross-border area as well as & Strong \\
& its external attractiveness to firms and skilled labour & Moderate \\
& & Weak \\
& & Not present \\
Border issues & Address the day-to-day challenges and opportunities & Strong \\
& associated with flows of people, goods and services (including & Moderate \\
& public services) across the border & Weak \\
& & Not present \\
\hline
\end{tabular}

Note: The assessment of relevance relates to the actual relevance in current cross-border collaboration, not necessarily to the potential relevance.

The main rationale for establishing a Helsinki-Tallinn cross-border area is to solve challenges related to cross-border flows of goods and people. Political views for the Helsinki-Tallinn cross-border area are driven by the goal of creating a more integrated market for labour, goods and services, as well as addressing the planning and environmental implications of increased traffic. For these two small economies, expanding to the neighbouring market is one incentive. Improved transport infrastructure within, around and between the two capital regions is therefore a core issue.

While peripheral in a European context, albeit sharing proximity to the Russian Federation, this cross-border link in the Baltic Sea is a shared issue that impacts cross-border flows. The Helsinki-Tallinn Transport and Planning Scenarios is a significant project, recently completed and funded by Interreg IVA, which investigated the various aspects of cross-border physical connections (Box 2.1). Under focus are both proximity linkages within the cross-border area and the role of the area as a hub in long-distance transport flows in the Baltic Sea region. For Finland, this connection is strategic, as Estonia is an important land connection to many European countries. The ports of Tallinn and Helsinki have started a twin-ports process (Merk et al., 2012). They are also developing gas and electricity interconnected grids to achieve greater energy supply security. Both sides of the border also share an interest in opportunities in the Russian market, as well as the possible negative implications of environmentally unfriendly activities in the gulf. 


\section{Box 2.1. Helsinki-Tallinn Transport and Planning Scenarios}

The H-TTransplan project organised the collaboration of planning authorities and stakeholders in the transport sector in the Tallinn and Helsinki regions from 2011-12. The project focused on the integration of Helsinki-Tallinn capital regions from the point of view of transport and infrastructure planning in the region. A large number of stakeholders from the public, private and academic sectors have been involved in discussing future scenarios of the region and plans related to: local and regional transport systems; transnational transport corridors; and hubs and logistics centres affecting the development of the Baltic Sea eastern shore as a whole. This project forms part of the institutional platform "Rail Baltica Growth Corridor" for the joint development and co-operative activities of public and private stakeholders acting for the promotion of Rail Baltica, an EU-promoted investment project that would provide a new north-south rail connection in the Baltic Sea region. The project involved a survey on business mobility and commuting, a territorial impact assessment, and the development of four scenarios for Helsinki-Tallinn transport and infrastructure development. The work includes co-ordination of information flows between the two city-region planners.

Source: Tapaninen, U. (2012), Helsinki and Tallinn on the Move: Final Report of the H-TTransPlan Project, Tallinn-Helsinki; www.euregio-heltal.org/httransplan.

The idea of "science twin-city" has been raised since the early times of cross-border cooperation as a way to build knowledge-intensive greater critical mass, but is not yet a formal strategy. Politicians have expressed the wish to develop knowledge exchanges, dating back to the first high-level events of the Helsinki-Tallinn Euregio. ${ }^{8}$ The opening speech at the 2003 forum mentioned: "I am especially content that...our most innovative idea was initiated - establishing and developing the science twin-city. The core of the science twin-city project is developing co-operation between science parks and business incubators. It is important to acknowledge that when Tallinn and Helsinki would join their resources in certain areas and make better use of their strongest features, then they can be more successful when competing with international metropolises" (Maripuu, 2003). The two Wise Men reports from 2003 and 2008 provided several recommendations pertaining to the development of cross-border research and education (Ollila and Jõerüüt, 2003; Blomberg and Okk, 2008). However, despite the presence of several interesting cross-border initiatives touching on innovation (see Chapter 4), and recent dialogue between the two Science Councils (see Chapter 3), this driving force has thus far played only a marginal role in the overall governance of the Helsinki-Tallinn cross-border area.

Complementarities with respect to innovation assets are potentially very relevant for crossborder collaboration, but complementarities in price differentials have dominated. Not only does the "science twin-city" concept support greater critical mass and visibility, it also raises opportunities to better map where those assets are complementary, creating a unique combination that contributes to the competitiveness of the cross-border area. Such complementarities could include, for example, e-service expertise in Estonia with application development in Finland (see Chapter 4). At present, firms appear to be primarily taking more advantage of the price differentials as a motivation for their cross-border collaboration.

Branding is a motivation on both sides of the border to overcome its peripheral location within Europe, such as for attracting investment and tourism. Developing a larger offer for cultural events on both sides of the gulf is also an objective which is seen as beneficial for both sides of the cross-border area. It supports the wider branding of the region while also promoting greater cross-border integration and identity along cultural lines. Branding the cross-border region is also considered useful for attracting foreign investment to better compete with other investment locations, notably Stockholm. Design branding is another field that both sides of the border seek to promote. 


\subsection{Role of key actors in cross-border area establishment and evolution}

Local authorities and transport operators play a key role in strengthening the integration of the Helsinki-Tallinn cross-border area. In line with the key orientation of Helsinki-Tallinn towards a more integrated region with better physical connections, the main actors involved in the establishment of the cross-border area are the two city authorities (and in particular their planning and transport offices); transport operators (ferry companies, port authorities and operators); and chambers of commerce and business support bodies on both sides.

Enterprise Helsinki and Enterprise Estonia facilitate cross-border trade and investment flows. Given the important cross-border investments, business development agencies active on both sides of the border provide support in various forms. For example, Enterprise Estonia has a permanent representative office in Finland. There is a Finnish-Estonian Chamber of Commerce in Estonia and a Finnish-Estonian Trade Association in Finland. The Estonian Development Foundation launched a start-up programme jointly with Aalto University in Finland.

Public research and tertiary education organisations establish ad hoc bottom-up co-operation. Thanks to their tradition of student mobility and joint research, universities and public research organisations initiate $a d$ hoc and informal co-operation, including with Interreg funds (see Chapter 4).

Table 2.2. Key innovation actors in the cross-border area

\begin{tabular}{|c|c|c|}
\hline & Helsinki & Tallinn \\
\hline Firms & $\begin{array}{l}\text { Top } 10 \text { companies: ICT: Nokia, Oil: Neste } \\
\text { Oil, SOK, Pulp and paper: Stora Enso, } \\
\text { UPM Kymmene, Kesko, Retail: Metso, } \\
\text { Energy: Fortum, Finance: Op Pohjola } \\
\text { Ryhmä, Insurance: Sampo }\end{array}$ & $\begin{array}{l}\text { Top } 10 \text { companies: Energy: Eesti Energia Ltd, } \\
\text { Shipbuilding: BLRT Grupp Ltd; Security: G4S Eesti Ltd, } \\
\text { Post \& telecom: Eesti Post Ltd, Elion Ettevõtted, Food: } \\
\text { Rimi Eesti Food Ltd, Distribution: Selver Ltd, Transport: } \\
\text { Hansaliin (Tallink also significant), ICT: Aktsiaselts } \\
\text { "Ericsson Eesti", Electronics: PKC Eesti AS }\end{array}$ \\
\hline $\begin{array}{l}\text { Business } \\
\text { services } \\
\text { organisations }\end{array}$ & $\begin{array}{l}\text { Culminatum (regional business } \\
\text { development agency) } \\
\text { Helsinki Business and Science Park Ltd } \\
\text { (private park) } \\
\text { Otaniemi Science Park Ltd (private park) } \\
\text { Enterprise Helsinki (city business } \\
\text { development agency) }\end{array}$ & $\begin{array}{l}\text { Tehnopol, Technopolis Ülemiste (private park) } \\
\text { Tallinn University of Technology Innovation Centre } \\
\text { Enterprise Estonia (national business development } \\
\text { agency) } \\
\text { Tallinn Enterprise (city business development agency) } \\
\text { Eures office (European job mobility service) }\end{array}$ \\
\hline $\begin{array}{l}\text { Public research } \\
\text { and tertiary } \\
\text { education } \\
\text { organisations }\end{array}$ & $\begin{array}{l}\text { University of Helsinki } \\
\text { Aalto University } \\
\text { Hanken, VTT Technical Research Centre } \\
\text { of Finland } \\
\text { National Public Health Institute (KTL) }\end{array}$ & $\begin{array}{l}\text { Tallinn University, Tallinn University of Technology } \\
\text { (TUT) } \\
\text { National Institute of Chemical Physics and Biophysics } \\
\text { University of Tartu (located outside of Tallinn region, } \\
\text { largest university in Estonia) }\end{array}$ \\
\hline
\end{tabular}

Source: Helsinki-Tallinn Euregio (2013), "Background report for OECD study on cross-border regional innovation policies: Helsinki-Tallinn".

\subsection{Barriers for cross-border co-operation linked to actors}

Major firms and higher education institutions (HEIs) tend to favour international co-operation opportunities, as opposed to proximate cross-border opportunities. In both countries, the need to internationalise activities is increasingly recognised given the small size of their domestic markets. While this is not contradictory to a search for opportunities in the neighbouring country, the latter opportunities are sometimes neglected. Public funding sources, such as the EU Framework Programme, often encourage multilateral, rather than bilateral collaboration. The current use of EU Structural Funds on both sides of the gulf only encourages local activities. The lack of clear identification of potential on either side of the border is a barrier for identifying the potential and the relevant actors for cross-border partnerships. 
The wider Baltic Sea region is increasingly seen as a relevant area for co-operation by investment and business promotion agencies. The Greater Helsinki Investment Agency is moving increasingly towards a Baltic Sea region co-operation approach. Business promotion agencies also cooperate in the wider Baltic Sea region context, such as the initiative "Baltic Sea Region Investment Agencies" (within the One Baltic Sea EU project) aimed at improved co-operation in investment promotion at this wider level. This is an opportunity for the cross-border region but it can also change the balance of power towards the western side of the Baltic Sea region, at the expense of the Finnish-Estonian side. 


\section{CHAPTER 3}

\section{GOVERNANCE OF THE HELSINKI-TALLINN CROSS-BORDER AREA}

Table 3.1. Snapshot of governance characteristics

(Helsinki-Tallinn in bold)

\begin{tabular}{|c|c|c|}
\hline Characteristic & Specification & Comments \\
\hline National political capitals & $\begin{array}{l}\text { Yes, each side } \\
\text { Yes, at least one } \\
\text { None }\end{array}$ & $\begin{array}{l}\text { The cross-border area includes the wider } \\
\text { capital area (city-region) on each side. This } \\
\text { creates close relationships with national } \\
\text { governments and institutions. }\end{array}$ \\
\hline $\begin{array}{l}\text { Longevity of public co-operation } \\
\text { (social proximity) }\end{array}$ & $\begin{array}{l}>20 \text { years } \\
10-20 \text { years } \\
<10 \text { years }\end{array}$ & $\begin{array}{l}\text { Cross-border activities started with the } \\
\text { establishment of the Euregio as an informal } \\
\text { network in } 1999 \text { and a formal body in } 2003 . \\
\text { Note that management of European Territorial } \\
\text { Co-operation (Interreg) is performed by another } \\
\text { entity, although the Euregio has managed } \\
\text { several Interreg projects. }\end{array}$ \\
\hline $\begin{array}{l}\text { Innovation policy competencies } \\
\text { (institutional proximity) }\end{array}$ & $\begin{array}{l}\text { Balanced, strong } \\
\text { Balanced, weak } \\
\text { Unbalanced }\end{array}$ & $\begin{array}{l}\text { On both sides, the main competences for } \\
\text { innovation policy are located at the national } \\
\text { level. However, both Finnish and Estonian } \\
\text { counties and cities are active in business } \\
\text { development promotion. }\end{array}$ \\
\hline $\begin{array}{l}\text { Political commitment } \\
\text { (institutional proximity) }\end{array}$ & $\begin{array}{l}\text { Balanced, strong } \\
\text { Balanced, weak } \\
\text { Unbalanced }\end{array}$ & $\begin{array}{l}\text { There is political alignment at the national level } \\
\text { on the wish to deepen co-operation linkages } \\
\text { between the two countries overall, including } \\
\text { high level meetings of national leaders. There is } \\
\text { also specific twin-city action. The overall } \\
\text { commitment may be somewhat stronger from } \\
\text { the Estonian side. }\end{array}$ \\
\hline $\begin{array}{l}\text { Institutionalisation and } \\
\text { legitimacy } \\
\text { (institutional and social } \\
\text { proximity) }\end{array}$ & $\begin{array}{l}\text { Present, strong } \\
\text { Present, weak } \\
\text { Not present }\end{array}$ & $\begin{array}{l}\text { Helsinki-Tallinn Euregio is a dedicated } \\
\text { institution responsible for the promotion of } \\
\text { cross-border relationships. Its visibility and its } \\
\text { mandate are limited and its future sustainability } \\
\text { uncertain. }\end{array}$ \\
\hline Actors in governance & $\begin{array}{l}\text { Public sector } \\
\text { University/research actors } \\
\text { Firms } \\
\text { Mix of actors (triple helix) }\end{array}$ & $\begin{array}{l}\text { The governance of the Euregio involves the } \\
\text { public sector, and there are no other formal } \\
\text { consultation bodies or working groups for wider } \\
\text { stakeholder participation (i.e. firms and } \\
\text { universities). }\end{array}$ \\
\hline Funding sources & $\begin{array}{l}\text { Mainly public } \\
\text { Mixed public/private } \\
\text { Mainly private }\end{array}$ & $\begin{array}{l}\text { Most of the joint activities in the innovation area } \\
\text { are funded through European Territorial Co- } \\
\text { operation programmes. Private co-financing of } \\
\text { these activities remains low. }\end{array}$ \\
\hline
\end{tabular}




\subsection{Vision for the cross-border area}

The current vision for Helsinki-Tallinn is centred on its role as a logistics and transport hub in the Baltic Sea region. Much of the twin-city work is focused on these spatial planning considerations. The latest strategy for Euregio, covering the period 2009-13, indicates three priorities for the cross-border partnership. They are: 1) increased interaction in spatial and regional planning; 2) creation of an innovative and a barrier-free region with common well-functioning markets; 3) development of a twin-region of arts and sciences (also referred to as a Knowledge Arena, the yearly event where stakeholders of the triple helix community gather to discuss the issue). Its main current activities (annual forum and projects) focus on these three priorities. The area of most progress, and perceived success by political stakeholders, has been on the development of a joint transport strategy for Helsinki-Tallinn, with the view of improving the mobility of goods and people throughout the area.

\subsection{Institutionalisation and multi-level governance of cross-border co-operation}

The cross-border co-operation is institutionalised through a co-ordination body, Helsinki-Tallinn Euregio NPA. The Euregio is a non-profit association of public authorities: the City of Helsinki, the City of Tallinn, the Uusimaa Regional Council, the Union of Harju County Municipalities and the Republic of Estonia, represented by the Harju County Government. It performs two functions: 1) it acts as a political discussion platform; and 2) it initiates and follows up on cross-border and inter-regional projects and networking according to priorities. The Board and the Secretariat are composed of representatives from these authorities. Within these governance bodies, there is a strong reliance on bilateral relationships between the two cities. The association appoints ad hoc working groups, dealing with priority issues. These have been: information society, rescue operations, vocational education, training, science twin-city, and currently a group that explores the feasibility of a cross-gulf tunnel.

National and regional innovation policies do not explicitly incorporate a goal of fostering crossborder co-operation in innovation. The current innovation policies in both countries do not display a particular focus on the cross-border potential for innovation. While internationalisation is a strong strategic direction in both cases, particular benefits to be reaped from cross-border innovation alliances and partnerships within the Helsinki-Tallinn cross-border area are not identified. Internationalisation and crossborder activities can be mutually enforcing, but can require different instruments to maximise their respective potential.

Innovation policies in the two countries show similarities. The recent development of innovation policy in Estonia has taken inspiration from the Finnish model; hence the two systems show a large degree of compatibility. Recent innovation policies across the sub-national regions around the Baltic Sea show a convergence in focus in two fields, ICT and materials and nanotechnology (Technopolis, 2011).

The two national R\&D and Innovation Councils have started working together. The most recent Wise Men report on Finnish-Estonian co-operation recommended that a joint Finnish-Estonian R\&D and Innovation Council be created (Bloomberg and Okk, 2008). While a new council replacing the two national councils does not constitute a relevant option, joint work between the two councils is a realistic option. The council has met three times, in 2004, 2008 and 2012. The main subjects where co-operation is seen as profitable by the councils are: 1) research infrastructure, where indivisibilities and high costs justify joint investments; and 2) cross-border participation in evaluation panels, made possible by physical and language proximity. The councils work under the supervision of the respective Prime Ministers and include university rectors, representatives of the Prime Ministers' Offices and Ministries of Education. 


\subsection{Funding for cross-border co-operation}

National policy instruments do not allow cross-border funding. As is the case generally for national governments, funding programmes in Estonia and Finland are, in principle, open for participation of - but not for funding to - foreign actors. Research and innovation actors, as long as they are registered in Finland, can benefit from national funding sources. This policy also applies to firms with foreign ownership, a provision more liberal than that in other countries where foreign-owned firms are often excluded from support schemes. Programmes are not aligned across borders (through joint calls with separate funding flows). Finland's innovation agency, Tekes, has the flexibility to adapt some of its programmes to a greater extent than other countries. For example, it had a joint R\&D programme with Sweden in the wood sector.

Public funding for cross-border co-operation in innovation is mainly provided by European Territorial Co-operation (Interreg) funding. The Helsinki-Tallinn cross-border area (and the rest of Estonia) is specifically covered by one strand under the Central Baltic Interreg programme (Box 3.1), which makes it easy to tailor the funding source to the relevant area for innovation. Competitiveness and innovation are important priorities under this programme.

\section{Box 3.1. Central Baltic Interreg IVA}

The Cross-border Co-operation Operational Programme "Central Baltic Interreg IV A" (2007-13) provides Community support for certain regions of Estonia, Finland (including Åland), Latvia and Sweden under the European Territorial Co-operation Objective. It includes three geographic sub-programmes:

- Archipelago and Islands sub-programme

- Central Baltic Programme

- Southern Finland-Estonia sub-programme, which includes the Helsinki-Tallinn area

The total budget of the programme is EUR 133 million and includes Community funding through the European Regional Development Fund (ERDF) of EUR 102 million. This represents approximately $1.2 \%$ of the total EU investment earmarked for the European Territorial Co-operation Objective under the Cohesion Policy 2007-2013. The programme contains three priorities in addition to a technical assistance line:

- Priority 1: Safe and Healthy Environment (27.1\% of total funding): This priority focuses on protecting and improving the common environment of the Central Baltic area and places special emphasis on protecting the Baltic Sea itself. It also focuses on supporting sustainable environmental development in the area.

- Priority 2: Economically Competitive and Innovative Region (39.8\% of total funding): This priority focuses on enhancing the overall economic development and competitiveness of the area. Emphasis is put on innovation, the development of connections to facilitate cross-border co-operation and better flows of goods and people, improvements in how the labour force is used and development of the tourism sector.

- Priority 3: Attractive and Dynamic Societies (23.9\% of total funding): This priority addresses the health, well-being and security of the population as well as co-operation for strengthening cultural exchange and cohesion in the area covered. The aim is to create a region with equal opportunities for different groups of the population and support their active participation in society. 


\subsection{Barriers for cross-border co-operation linked to governance and funding issues}

The Euregio Secretariat has limited opportunities to foster the cross-border area. It has a technical assistance role, working somewhat behind the scenes. It lacks wider recognition from many leading public and private actors. With a permanent staff of two, and infrequent meetings with staff from member public entities, its role in driving the partnership and in identifying successful bottom-up trends in co-operation is limited. Participants from the public authorities represented in the different working groups typically only devote a small share of their time to supporting the Euregio's activities. The long-term sustainability of the Euregio has also been raised by its funding public authorities.

The governance structure only includes public actors. The development of Helsinki-Tallinn as a functional area is a top-down project from mainly local and regional public authorities, in part because the focus has been on transport and planning. As innovation has not been the primary focus thus far, firms, education and research actors are not involved in the governance bodies. However, there is potential for the other actors in the "triple helix" to lead many trans-border partnerships and initiatives.

The European Territorial Co-operation (Interreg) funding source presents a number of deficiencies, here as in other cross-border areas. Interreg is the primary funding source to support crossborder innovation experiments and programmes. It fills a gap in projects that are not easily funded by aligning separate funding sources on both sides of the border. However, Interreg suffers from a number of drawbacks. By definition, Interreg uses a project-based approach. However, the projects are not necessarily embedded in a broader strategy to which the individual projects contribute. Another drawback is that while the programme is meant to fund catalytic initiatives, long-term impacts are rarely assessed. The projects often remain at the "proof of concept" stage, without the follow-up for larger scale implementation when relevant. Many of the programmes emphasise networking and exchanges rather than more concrete results in terms of joint innovation collaboration. A corollary from this is the lack of project sustainability at the end of the Interreg funding period. This also implies insufficient private sector engagement at the inception of projects that would be a greater guarantee of long-term viability. Unlike for some other Interreg programmes in Europe, in this case the sub-programme actually does fit with the relevant geographic area for innovation activities which is one advantage.

Data on cross-border flows has served the needs of the cross-border area, but they do not cover knowledge flows. The Euregio has been quite active in generating and collecting data on cross-border transport, freight, commuting and other economic flows. This information is very useful for monitoring the state of integration of the cross-border area. Data on knowledge potential and flows are missing, however, which impedes the identification of opportunities and bottlenecks for cross-border innovation co-operation and initiatives. 


\section{CHAPTER 4}

\section{HELSINKI-TALLINN CROSS-BORDER INNOVATION POLICY MIX}

\subsection{Cross-border initiatives and policy instruments}

The most recent and significant joint initiatives between Helsinki-Tallinn relate to transport and infrastructure development. Currently, the main initiatives are two EU-funded projects: 1) the Helsinki-Tallinn Transport and Planning Scenarios (HTTransPlan, see above); and 2) the Rail Baltica Growth Corridor, which address strategies for improving transport infrastructure. Previous projects implemented under the Euregio Helsinki-Tallinn include: the Baltic Euroregional Network (2005-07), a capacity building and networking project for Euroregions (including nine Baltic Sea countries); a feasibility study of a joint ticket system for public transport in Helsinki-Tallinn (2005-06); and Huuta, a project for prevention of drug use and sexually transmitted diseases (2005-06). An exception to this list is the innovation-related Helsinki-Tallinn Science Twin-City project (2002-05), which aimed to promote cooperation of science parks in the two city areas by fostering the mobility of staff and students as well as by facilitating joint business development. The project led to the organisation of network events, sharing of office facilities and the production of reports (see below).

In the field of innovation, there are no long-term joint policies but rather a number of temporary initiatives aimed at mutual exchanges in entrepreneurial activities. Joint Finnish-Estonian projects such as StartSmart and the Network of Finnish and Estonian incubators (Box 4.1), as well as the Estonian-Finnish Design challenge (Box 4.2), are all temporary projects funded by Interreg. They focused on developing mutual knowledge and joint actions in the area of entrepreneurship in the IT/creative sector. The co-operation between Tehnopol in Estonia and Aalto University in Finland around start-up promotion (Startup Sauna) is another example in the same field, with a strong bottom-up drive. Joint matchmaking services are provided by Technopolis on a cross-border basis in the form of breakfast meetings and money talks (matchmaking of investors with growth companies), among other activities. The cross-border area would therefore benefit from a more broad-based joint strategy to help ensure that these different initiatives contribute to a recognised cross-border regional goal.

\section{Box 4.1. Examples of cross-border incubator collaboration and start-up support}

Start-Smart is a co-operative cross-border project financed by the Interreg IV A Programme 2007-13, Southern Finland-Estonia. The partners are: the Estonian Development Fund (lead partner), the Small Business Centre of Aalto University in Finland, BDA Consulting OÜ, Enterprise Estonia, and AS Technopolis Ülemiste in Estonia. The aim is to support entrepreneurial attitudes in both countries and accelerate the emergence of innovative enterprises. Activities include: workshops and seminars in Estonia and Finland with international speakers; start-up demo pitching nights; a mapping of the Estonian and Finnish start-up ecosystem; a start-up database; one-to-one mentoring; one-to-one consultancy (for business plan development, business modelling or marketing) and awareness raising via social media channels.

The Cross-Border Small Business Environment project established a network between southern Finnish and Estonian business incubators, with the goal to develop business activities and competitiveness of the Finnish and Estonian companies participating in the project in three main activities:

- network development of Finnish (southern Finland) and Estonian business incubators

- the development of a training programme for the managers of business incubators and technology parks, which include a best practice exchange and implementation

- the provision of support and information services for Finnish and Estonian companies in developing their business activities and competitiveness 


\section{Box 4.1. Examples of cross-border incubator collaboration and start-up support (cont.)}

The project has provided market surveys, consulting, training services and thematic seminars for southern Finnish and Estonian SMEs. Participants in the project gained new business partners and customers, as well as knowledge about the Finnish-Estonian business environment and cross-border business opportunities.

Startup Sauna, founded in 2010, is a non-profit organisation for start-ups and aspiring entrepreneurs in Northern and Eastern Europe and the Russian Federation. Its aim is to implement a blooming start-up ecosystem and a pay-it-forward culture into the region in order to make it the best place to be a start-up. Startup Sauna is physically located on Aalto University's campus in Espoo, Finland (Helsinki metropolitan area). Run by its own foundation, Startup Sauna is funded by Aalto University, Teknologiateollisuus, Sitra and Tekes, among others. In practice, Startup Sauna consists of three different operations:

- An internship programme for aspiring entrepreneurs to work at high-growth companies in Helsinki and Silicon Valley. More than 60 interns have been matched to date through the programme.

- An accelerator programme for early-stage start-ups from northern Europe and the Russian Federation, where the companies are coached by experienced serial entrepreneurs and investors in an intense one-month programme in Helsinki. Ninety companies have graduated from the programme since 2010 , with more than USD 25 million of funding raised.

- The Slush conference, which brings together the early-stage start-up ecosystem in the region to meet top-tier venture capitalists and media from around the world.

Source: Presentation during OECD mission, 9-11 April 2013; www.pyk.hkkk.fi/crossbent; http://slush.fi/

\section{Box 4.2. Estonian and Finnish Design Challenge}

The 2006-07 project "Estonian and Finnish Design Challenge", funded under Interreg IIIA, aimed to develop new products, activity models and networks through co-operation between Finnish and Estonian designers and companies. The lead partner was Baltic Design \& Interior Network from Finland. The other partners were Estonian: the Business and Development Centre of Pärnu County, the Vocational Centre of Pärnu and Tehnopol.

During the project, ideas and solutions for furbishing public rooms were developed. The results were displayed at an exhibition, "Smart Hotel", which took place in Tallinn and Helsinki. The project also targeted the markets of St. Petersburg. The project resulted in new innovative schedules and prototypes, co-operative networks between Estonian and Finnish designers and companies, a pilot model of "Design Start" and increased knowledge in design.

Source: www.baldesign.net.

The Helsinki-Tallinn Science Bridge project was an early attempt to develop cross-border university co-operation for science parks. In the period 2002-05, the Science Twin-City project, a Helsinki-Tallinn Euregio project with Interreg funding, aimed at fostering co-operation among actors in science parks in the regions of Helsinki and Tallinn. It included: mapping the opportunities for cooperation, brokerage events in key technology fields and co-operation in the supply of office space and other science park services. The key actors were universities on both sides of the border. The project included a mapping of existing university co-operation activities and interests, readiness and preconditions of university administrations, and relevant faculties and departments to intensify co-operation. ${ }^{9}$ The need and the potential for closer cross-border co-operation in science and innovation are highlighted in Krigul (2011) and Lepik (2010).

Several bilateral co-operation agreements exist between universities in the Helsinki-Tallinn area as well as other researcher-based co-operations. Universities in the cross-border area have a long tradition of co-operation, which increased after 1991. This takes the form of student, teacher and researcher exchanges, joint researcher training, co-publications, joint conferences and EU-funded project co- 
operation. The University of Helsinki has bilateral collaboration agreements with the University of Tartu, Tallinn University, the Tallinn University of Technology and the Estonian Agricultural University. However, a past study in the life sciences sector found that research collaboration was based mainly on activities initiated by an Estonian researcher moving to the greater Helsinki region, and less so in the other direction (Hydrios Biotechnology Ltd, 2004). Co-operation also takes place with public research institutes, with VTT and Estonian actors active in the fields of energy, environmental and marine research.

Joint university participation in multilateral $R \& D$ projects is likely more intense than bilateral co-operation. Since Estonia's accession to the EU, most co-operations in the sphere of higher education have taken place within the context of EU programmes. Both the Tallinn University of Technology and the University of Helsinki are members of the Baltech Consortium, which is a consortium of nine universities of technology in the Baltic Sea area (Helsinki, Tallinn, Kaunas, Riga, Vilnius, Stockholm, Lund, Linköping and Copenhagen). Baltech members are involved in research collaboration, notably by submitting joint project proposals to the EU Framework Research programme. The two countries have shared interests in the European Strategy Forum on Research Infrastructures (ESFRI) with joint participation in research infrastructure projects in the areas of biosciences (INSTRUCT and BBMRI), linguistics (CLARIN) and social sciences (ESS, the European Social Survey). Finland and Estonia also belong to ScanBalt BioRegion, which is a network within biotech in the Baltic Sea area. Its operations are funded by the Nordic Industrial Fund.

Tartu is present in cross-border $R \& D$ and innovation co-operation. The University of Tartu is part of many cross-border initiatives and instruments (e.g. brokerage events of the Science Twin-City project, Interreg-funded projects). This justifies an extension of the cross-border area definition to include Tartu as well as Tallinn, particularly for science-based instruments. Bibliometric data also shows active co-publication ties between the University of Tartu and the University of Helsinki. ${ }^{10}$

Exchanges also take place between funding agencies. The Academy of Finland and Estonian bodies providing research funding are jointly involved in several EU projects aiming at developing exchanges of good practice, and possibly, joint activities. In most cases, the partnerships extend beyond Finland-Estonia. For example, the BONUS project (Baltic Organisations' Network for Funding Science) gathers funding organisations in the Baltic Sea region to enhance co-operation. 
Table 4.1. Cross-border policy instruments in Helsinki-Tallinn

\begin{tabular}{|c|c|}
\hline Instruments & Programmes/initiatives \\
\hline \multicolumn{2}{|l|}{ Strategy and policy development } \\
\hline \multicolumn{2}{|l|}{ Benchmarking and policy learning } \\
\hline $\begin{array}{l}\text { Analytical exercise (mapping of clusters or value } \\
\text { chains, technology foresight exercises) }\end{array}$ & $\begin{array}{l}\text { Several reports and research, although not always with the } \\
\text { cross-border innovation aspect as the central theme of research }\end{array}$ \\
\hline \multicolumn{2}{|l|}{ Joint branding of cross-border area } \\
\hline \multicolumn{2}{|l|}{ R\&D support } \\
\hline Joint public research programmes & Cross-use of experts for project evaluation \\
\hline $\begin{array}{l}\text { Joint research infrastructure, shared access to } \\
\text { research facilities }\end{array}$ & $\begin{array}{l}\text { Mainly in the framework of ESFRI or larger consortia } \\
\text { (e.g. Sweden Max IV) } \\
\text { Joint discussion in the two research councils }\end{array}$ \\
\hline \multicolumn{2}{|l|}{$\begin{array}{l}\text { Cross-border private R\&D funding programmes } \\
\text { (generic and thematic) }\end{array}$} \\
\hline \multicolumn{2}{|l|}{ Technology transfer and innovation support } \\
\hline $\begin{array}{l}\text { Cross-border innovation advisory services } \\
\text { (vouchers, intermediaries) }\end{array}$ & $\begin{array}{l}\text { Finnish-Estonian Chamber of Commerce } \\
\text { Finnish-Estonian Trade Association }\end{array}$ \\
\hline $\begin{array}{l}\text { Advisory to spin-off and knowledge-intensive } \\
\text { start-ups }\end{array}$ & StartSmart \\
\hline \multicolumn{2}{|l|}{$\begin{array}{l}\text { Other technology transfer centres and extension } \\
\text { programmes }\end{array}$} \\
\hline \multicolumn{2}{|l|}{ S\&T parks and innovation networks } \\
\hline $\begin{array}{l}\text { Cross-border science, technology parks and } \\
\text { incubators }\end{array}$ & $\begin{array}{l}\text { Mutual contact points in science parks and incubators; Office of } \\
\text { Helsinki School of Economics in Tallinn Technology Park } \\
\text { Tehnopol; joint mentoring programme under development; } \\
\text { networks between southern Finnish and Estonian business } \\
\text { incubators }\end{array}$ \\
\hline \multicolumn{2}{|l|}{ Cluster or networks initiatives } \\
\hline \multicolumn{2}{|l|}{ Human capital } \\
\hline \multicolumn{2}{|l|}{ Scholarships/student exchanges } \\
\hline $\begin{array}{l}\text { Joint university or other higher education } \\
\text { programmes }\end{array}$ & Joint doctoral schools \\
\hline $\begin{array}{l}\text { Talent attraction, retention or mobility scheme; } \\
\text { cross-border labour market assistance }\end{array}$ & EURES (EU cross-border mobility services) \\
\hline \multicolumn{2}{|l|}{ Other instruments } \\
\hline $\begin{array}{l}\text { Financing (venture capital funds or angel } \\
\text { networks) }\end{array}$ & $\begin{array}{l}\text { Business angels working cross-border (not a specific policy } \\
\text { per se) }\end{array}$ \\
\hline \multicolumn{2}{|l|}{ Public procurement } \\
\hline Other & $\begin{array}{l}\text { Finnish implementation of a data exchange layer infrastructure } \\
\text { akin to the Estonian X-Road (facilitating cross-border secure data } \\
\text { exchange to support public services and firms) }\end{array}$ \\
\hline
\end{tabular}

\subsection{Untapped potential for promoting cross-border innovation synergies}

Developing and branding the area as an entrepreneur-driven hotspot for innovation is an opportunity for Helsinki-Tallinn. Without disputing the importance of the area as a well-connected and strategic transport hub, the potential for developing it as a dynamic knowledge-based area is under developed. The on-going initiatives listed in Table 4.1 indicate that there is potential and enthusiasm from field actors to exploit complementarities across the border to develop the area as an innovation hub in the broader Baltic Sea region. 
Life sciences, ICT and new materials are areas which have been identified as having potential for joint knowledge-based activities. Within the frame of the Science Twin-City project, workshops and studies have focused on specific areas for collaboration identified those areas.

Another area with promising potential for both sides is the development of e-society applications. The list of possible applications where Estonian and/or Finnish companies and local authorities face opportunities to jointly develop advanced applications is potentially very long. For example, the Finnish government will adopt a data exchange layer akin to the Estonian X-Road, creating new opportunities to support public and private sector e-society developments (Box 4.3 and Figure 4.1). In many of areas, the two countries can unite forces to test new applications in their small markets as a first step before further diffusion in international markets. Using Helsinki and Tallinn as test-bed medium-sized cities for advanced smart city applications is one opportunity. Tallinn has extensive experience in several applications. The organisation Forum Virum Helsinki is active in promoting the development of smart and innovative solutions at the city level. Some examples of potential applications to consider for cross-border development are:

- joint city e-services

- cross-border billing and banking services

- e-identification applications

- design/gaming applications

- media/audio-visual communication tools.

\section{Box 4.3. The X-Road: Data exchange layer from Estonia to be adopted in Finland}

The Government of Finland will adopt a data exchange layer akin to the Estonian X-Road to be in full use by 2015. The data exchange layer X-Road, launched in Estonia in 2001, is a technical and organisational environment, which enables secure Internet-based data exchange with the state's information systems. It is the invisible backbone of e-Estonia that allows the nation's various e-services databases, both in the public and private sector, to link up. The X-Road is not only a technical solution. The X-Road allows institutions and people to securely exchange data as well as to ensure people's access to the data maintained and processed in state databases.

Public and private sector enterprises and institutions can connect their information system with the X-Road. This enables them to use X-Road services in their own electronic environment or offer their e-services via the XRoad. Joining the X-Road enables institutions to save resources, since the data exchange layer already exists. This makes data exchange more effective both inside the state institutions as well as for communications between a citizen and the state.

Additionally, the X-Road enables public enquiries, citizen access and efficiency of public services. For example, in Estonia this enables transfer of insurance data to the Estonian Health Insurance Fund. In order to use the services, the end users must first authenticate themselves with an ID card or via an Internet bank. The entrepreneur's right of representation is authenticated on the basis of the data of the Commercial Register. For citizens, the X-Road allows use of its services via different portals such as making enquiries from state databases and to control the information related to the person himself/herself. Public officials can use the services intended for them (such as the document exchange centre) in the information systems of their own institutions. This facilitates the officials' work, since it avoids the labour-consuming processing of paper documents, large-scale data entry and data verification. Communication with other officials, entrepreneurs and citizens is faster and more accurate. 


\section{Box 4.3. The X-Road: Data exchange layer from Estonia to be adopted in Finland (cont.)}

One of the key elements of e-Estonia is that its databases are decentralized, which means:

- There's no single owner or controller.

- Every government agency or business can choose the product that's right for them.

- Services can be added one at a time, as they are ready.

Originally X-Road was a system used for making queries to the different databases. Now it has developed into a tool that can also write to multiple databases, transmit large data sets and perform searches across several databases. Currently there are more than 800 organizations, public registers and databases connected to the XRoad and this number is increasing.

Source: https://www.ria.ee/public/x_tee/xRoadOverview.pdf

Figure 4.1. The Estonian information system and the X-Road data exchange layer

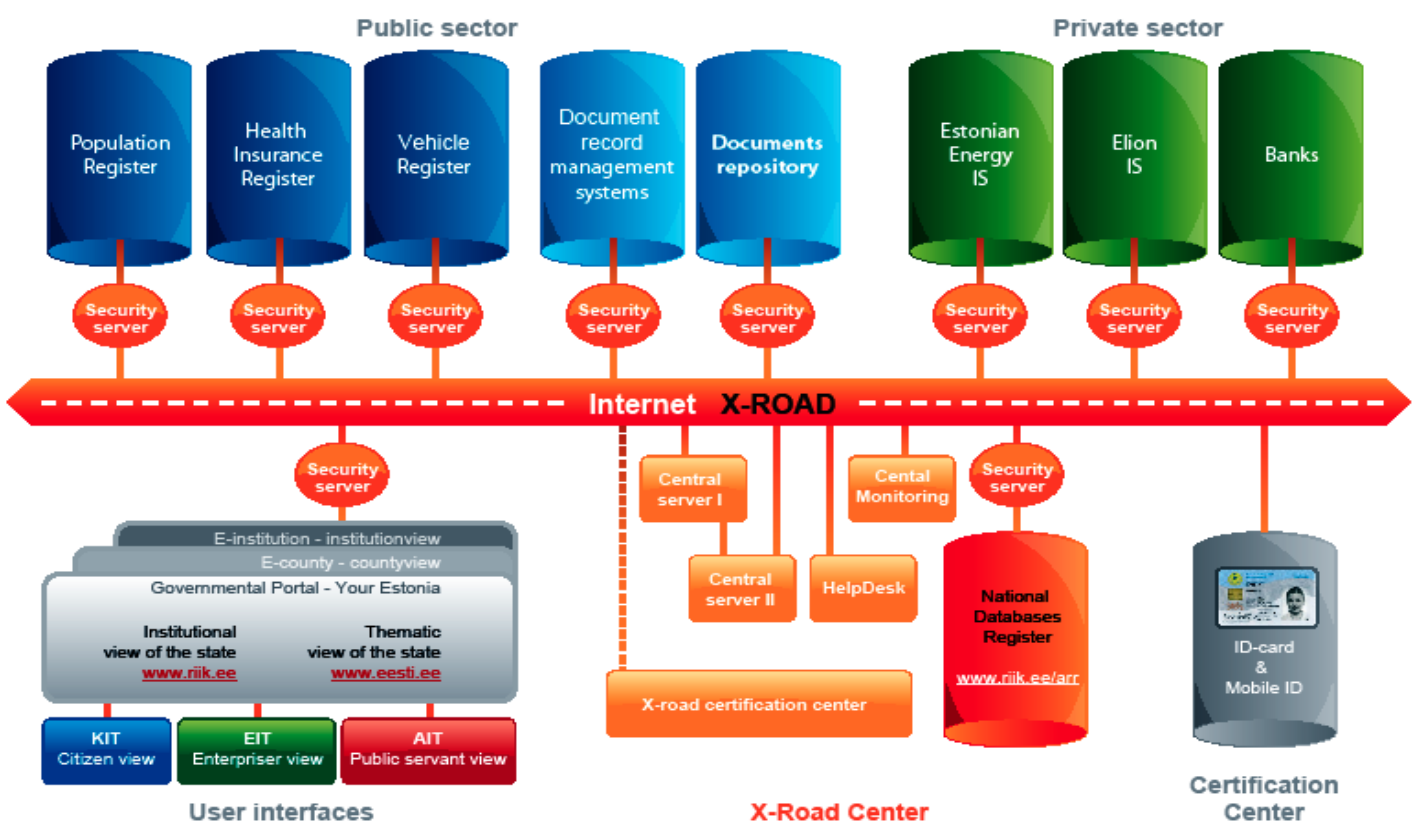

Source: https://www.ria.ee/public/x_tee/xRoadOverview.pdf

Life science applications also present co-operation opportunities. Biomedicine, genome research, bioinformatics and bioengineering have been identified as areas with potential for intensified research collaboration (resulting in joint research groups and programmes and joint participation in projects funded by different EU programmes). Opportunities for cross-border collaboration in this sector may already be underway, but options include: intensified co-operation in the development of research and commercialisation support structures (quality, intellectual property protection, licensing, etc.); intensified teacher, undergraduate and postgraduate student exchange (enabled by joint graduate school and Master's programmes); and shared use of expensive equipment and facilities (Hydrios Biotechnology Ltd, 2004).

Several types of joint academic activities in education and research could be further explored, with innovation goals in mind. The two Wise Men reports on Finnish-Estonian co-operation have both 
singled out research and education as fields with significant opportunities (Box 4.4). Ministerial support and buy-in from actors are needed to turn these proposals into concrete activities. The Science Twin-City project, carried out between 2002 and 2005, listed potential areas for joint co-operation between universities in Helsinki and Estonia. ${ }^{11}$ The project included meetings between universities and science parks and technopoles from the two sides of the Gulf of Finland. The proposed co-operation fields included activities in research and education, such as:

- common/joint graduate schools

- common undergraduate courses and lectures

- common research facilities

- mobility and exchange of graduate students, scientists and teachers through a joint scholarship system

The possibilities for joint activities under the third mission of universities were also inventoried:

- training of business incubation managers

- joint mentoring (in business incubators and/or spin-off programmes)

- brokerage events and co-operation in the supply of office space and other services in science parks

- co-operation in intellectual property rights (IPRs) issues

- screening and evaluation of technology development and innovations

- $\quad R \& D$ and innovation marketing.

The cross-border area could be developed as a $\mathrm{VC}$ zone for venture capitalists. The international VC Zone is a joint Finnish project (by Technopolis, SITRA, Tampere and Aalto University) aiming at developing a larger market for venture capitalists. The initiative could be extended to include Estonia, so as to increase the potential deal flow. This already occurs to a certain extent since Estonian investors are targeting Finnish firms. With a larger market, specialisation needed for VC funds is more likely. 


\section{Recommendations from the Ollila and Jõerüüt report in 2003}

- increase co-operation in postgraduate education

- increase co-operation in acquisition and utilisation of laboratories and other facilities

- increase the mobility of students and researchers

- increase co-operation in high-tech business development

- secure the possibilities for Finns to study in Estonia and for Estonians in Finland

\section{Recommendations from the Blomberg and Okk report in 2008}

\section{Research and development:}

- establish a joint Estonian-Finnish Science, Technology and Development Council along with a permanent Finnish and Estonian secretariat and an independent Estonian-Finnish think-tank

- establish concrete forms of co-operation between Enterprise Estonia and Tekes on the one hand, and the Estonian Development Fund and the Finnish Innovation Fund Sitra on the other

- establish partnerships and co-operation networks between research institutions (Aalto University, the Tallinn University of Technology and the Estonian Academy of Arts) and Estonian and Finnish design institutes in order to enhance co-operation in the field of creative work, commercialisation and marketing

- develop co-operation between Estonian and Finnish technology centres and enterprise incubators

- hold Estonian Science Days in Finland and Finnish Science Days in Estonia

\section{Education:}

- put procedures in place for Estonian and Finnish Ministries of Education to harmonise the training objectives and the use of resources of the two countries as well as to co-ordinate teaching programmes and the investments made in education

- establish a joint Estonian-Finnish institution named the Cross Gulf University with a focus on organising co-operation in postgraduate education

- $\quad$ establish a joint Estonian-Finnish training fund with public and private funds to support students and researchers, particularly those undergoing post-graduate training, with housing allowances and to facilitate the exchange of students between Finland and Estonia

- consider the possibility of establishing a joint office for Estonian and Finnish universities in the People's Republic of China or India

- $\quad$ promote the teaching of Estonian in Finland and the teaching of Finnish in Estonia

Sources: Ollila, E. and J. Jõerüüt (2003), Finland and Estonia in the European Union, Prime Minister's Publications, Helsinki; Blomberg, J. and G. Okk (2008), Opportunities for Co-operation between Estonia and Finland 2008, Prime Minister's Publications, Helsinki, 10/2008. 


\subsection{Relevance and effectiveness of the policy mix for cross-border co-operation}

Table 4.2. Snapshot of the innovation policy approach

(Helsinki-Tallinn in bold)

\begin{tabular}{|c|c|c|}
\hline Element of policy mix & Definition & Degree \\
\hline Information & Mutual exchange of data, actor mappings and policy information & $\begin{array}{l}\text { Strong } \\
\text { Moderate } \\
\text { Weak } \\
\text { Not present }\end{array}$ \\
\hline Experimentation & Ad hoc and temporary common initiatives without joint funding & $\begin{array}{l}\text { Strong } \\
\text { Moderate } \\
\text { Weak } \\
\text { Not present }\end{array}$ \\
\hline Alignment & $\begin{array}{l}\text { Mutual opening of programmes or structures across borders - no } \\
\text { joint funding }\end{array}$ & $\begin{array}{l}\text { Strong } \\
\text { Moderate } \\
\text { Weak } \\
\text { Not present }\end{array}$ \\
\hline Joint actions narrow & $\begin{array}{l}\text { Limited cross-border measures, structures and actions with joint } \\
\text { funding by actors from several regions }\end{array}$ & $\begin{array}{l}\text { Strong } \\
\text { Moderate } \\
\text { Weak } \\
\text { Not present }\end{array}$ \\
\hline Joint actions broad & Multiple joint instruments co-funded by the constituting regions & $\begin{array}{l}\text { Strong } \\
\text { Moderate } \\
\text { Weak } \\
\text { Not present }\end{array}$ \\
\hline Strategic policy mix & $\begin{array}{l}\text { Joint common strategy adopted at the level of the cross-border area, } \\
\text { translated into a common policy mix co-funded by all of the } \\
\text { constituting regions }\end{array}$ & $\begin{array}{l}\text { Strong } \\
\text { Moderate } \\
\text { Weak } \\
\text { Not present }\end{array}$ \\
\hline
\end{tabular}

Cross-border co-operation instruments mainly take the form of experimental networking and information exchanges. There is no joint programming, nor joint structural instruments to support innovation in the cross-border area. Existing co-operation stems from bottom-up initiatives, which are temporary and often dependent on public funding from EU or Nordic sources. The sustainability of these endeavours is not ensured, nor is the move beyond experimentation and proof of concept. Given the opportunities at stake, there is room to evolve towards cross-border measures, structures and actions with joint funding by actors from the two countries. In parallel, evolving towards a vision of the area as a knowledge hub would pave the way toward a joint strategy, which could then inform the development of a policy mix to support cross-border innovation. 


\section{CHAPTER 5}

\section{RECOMMENDATIONS FOR CROSS-BORDER INNOVATION IN HELSINKI-TALLINN}

Helsinki-Tallinn faces the opportunity to evolve from a price-driven functional economic area towards a knowledge-driven one. Today, integration forces between the capital regions of Finland and Estonia rely principally on price and wage differentials. These differences bring temporary benefits to both economies. They include the availability of lower cost labour and lower input prices for Finnish companies investing across the border and expanded employment opportunities for Estonian workers. Convergence in price and wage levels will take place and reduce these advantages. Exploiting to a greater extent the existing opportunities for joint business and complementarities in skills across the border can enhance the competitiveness of both economies. A reasonable degree of physical and social proximity in related sectors exists between the two city-regions to set the stage for such co-operation.

The objective of developing Helsinki-Tallinn as a logistic hub in a wider Baltic Sea context should be complemented by a goal of exploiting proximate diversity in innovation. The main vision shared by Helsinki-Tallinn governing bodies concerns the role of this hub in the nexus of transport corridors between Northern and Central Europe. A risk exists that the benefits from this position might be limited to the transport and logistics sectors, with few spillover effects to the rest of the economy. Another, complementary vision can be developed, geared towards the development of critical mass and an original combination of activities and competences for the development of innovative products and services with an international competitive edge. There is complementarity between, on the one hand, Estonian risk-taking and fast-moving attitudes, as well as the remarkable developments in e- and mobile services mostly driven by small firms, and, on the other hand, successful Finnish experience with the development of technologydriven products and services for the international market. Building new markets together in niche activities of Nordic excellence can serve both economies.

\subsection{Cross-border area}

Extend the definition of the cross-border area to Helsinki-Estonia, branded as an "entrepreneurial knowledge region"

- Extend the area to include the whole of Estonia. Knowledge actors in the whole of Estonia and especially in Tartu - can benefit from interactions with their Finnish neighbours. The fact that innovation policy is designed and implemented at the national level in Estonia, together with the small size of the country, also makes it more relevant to include all innovation system actors in the cross-border partnership.

- Brand the area as an "entrepreneurial knowledge region". Combining the strengths of Helsinki in science and technology, and the assets of Estonia as an entrepreneurial country is an opportunity to be tapped. Branding this concept can help this relatively small area to stand out in the Nordic area and the wider Baltic Sea and global arenas. 


\subsection{Governance}

Improve governance mechanisms to include a new "innovation" direction, reinforce the co-ordination function and bring in relevant actors

- Involve national governments. Most of the policies that can support or hinder innovation are under the responsibility of national governments in both Finland and Estonia. It would therefore be necessary to integrate national representatives in the governance structures. The annual review of co-operation opportunities between the two Prime Ministers could have a specific chapter on research and innovation, involving not only Ministers of Foreign Affairs but also those of Economy, Research and Innovation.

- Integrate the triple helix of actors in the governance of the cross-border region. Today, the Euregio is driven mainly by public authorities, the founding members of the association. To better reflect the potential for cross-border innovation in practice, it is necessary to include the field actors, notably research and education institutions and companies. This could take place through a consultative group, which would report regularly to the Board and the Secretariat.

- Further develop the joint work of the two national R\&D and Innovation Councils. As recommended in the latest Wise Men report, such activity should be supported by preparatory work undertaken by a bi-national taskforce in charge of studying the possible synergies between the two countries in the area of $R \& D$ and innovation. The joint council activities should target innovation in a broader sense and not be restricted to $R \& D$.

- Underpin cross-border innovation policy efforts with a stronger policy intelligence function that provides the relevant analysis and data. To support the governance of the cross-border area, there is a need for: 1) better information on innovation potential and complementarities across the two sides of the border (data on knowledge flows as well as public and public private $\mathrm{R} \& \mathrm{D}$ partnerships that complement the already existing information on flows of people and goods across the border); and 2) impact assessment of the pilot instruments deployed, mostly with Interreg funding. InterTradeIreland offers examples of how to support policy intelligence for cross-border innovation policy.

\subsection{Innovation policies and instruments}

Mainstream cross-border innovation into national programmes and focus on impacts and results in areas of strong expertise

- Mainstream cross-border policies in the work of Enterprise Estonia and Tekes (Finland). Investigate the possibilities on both Finnish and Estonian sides to: 1) align funding schemes; and 2) integrate cross-border funding possibilities when it can be demonstrated that benefits are arising on both sides of the border.

- Focus on results and impacts more than on co-operation platforms. Perform ex ante evaluations of cross-border projects for public funding on the basis of the potential for concrete results beyond the establishment of exchange platforms. Perform ex post evaluations on these grounds and refine policy instruments on the basis of the lessons learnt from the evaluations.

- Encourage opportunities in the joint development of e-society applications where skills in the cross-border area are particularly strong, among other priorities, for an overall strategy. Introduce a priority in these areas as a criterion for developing a cross-border policy 
mix. Developing a strategic vision for cross-border innovation activities would help the region to go from a "project-driven" to a more strategic approach, including this and other priorities identified by cross-border actors.

- Further develop the collaboration on entrepreneurship between incubators, technology centres, universities and venture capital funds. Strong entrepreneurship dynamics is an asset, and also a necessity for the cross-border area to thrive. This should constitute a horizontal priority for a cross-border policy mix for Helsinki-Tallinn, notably for the relevant framework conditions to enable this private sector-led activity to thrive.

\section{NOTES}

1. Data as reported on the national website Estonia.eu.

2. Data for 2009 from the OECD Regional Database, http://dx.doi.org/10.1787/region-data-en.

3. The Helsinki Investment Agency refers to "Greater Tallinn" as an area covering most of Estonia.

4. Per data from the Bank of Estonia.

5. As reported to OECD mission participants, 9-11 April 2013.

6. For example, non-residents cannot own a business in Finland without getting a permit and Finnish banks will not open a bank account for a foreign firm.

7. A helicopter accident had dampened market demand for helicopter services, although it is possible that there remains latent demand for helicopter services.

8. This was even an older joint interest: as early as 1937, the Estonian President and the Foreign Minister of Finland signed a Convention on Intellectual Co-operation between the Republic of Estonia and Finland. It is the oldest co-operation pact between the two countries, as it was never repealed by the Soviet Union. The convention states the main principles of educational co-operation: establishing cultural institutes, promoting universities and the exchange of students and professors, supporting organisations that advance co-operation, supporting the purchase of books for libraries, and theatre, art and news exchanges.

9. For more information, see www.euregio-heltal.org/activities/finalized-projects/science-twin-city/helsinkitallinn-science-twin-city-programme.

10. As reported by a representative of the University of Helsinki to the OECD mission team 9-11 April 2013.

11. For more information, see www.euregio-heltal.org. 


\section{REFERENCES}

Ajmone Marsan, G. and K. Maguire (2011), "Categorisation of OECD regions using innovation-related variables”, OECD Regional Development Working Papers, No. 2011/03, OECD Publishing, http://dx.doi.org/10.1787/5kg8bf42qv7k-en.

Blomberg, J. and G. Okk (2008), Opportunities for Co-operation between Estonia and Finland 2008, Prime Minister's Publications, Helsinki, 10/2008.

CIMO (2011), International Mobility in Finnish Vocational and Higher Education in 2010, Faktaa - Facts and Figures 1b/2011.

European Commission (2012), Regional Innovation Scoreboard, European Commission, Brussels.

European Research Area Committee (ERAC) (2012), Peer Review of the Estonian Research and Innovation System, European Commission, Brussels.

Heinonen, K. (2003), Helsinki-Tallinn Twin-City of Science Project: Co-operation in Education and R\&D and Advancement of Mobility, Culminatum Ltd Oy - Helsinki Region Centre of Expertise.

Helsinki-Tallinn Euregio (2013), "Background report for OECD study on cross-border regional innovation policies, Helsinki-Tallinn”.

Hydrios Biotechnology Ltd. (2004), Helsinki-Tallinn Twin City of Science: Life Science and Biotechnology Report, Culminatum Ltd Oy - Helsinki Region Centre of Expertise.

Krigul, M. (2011), "An analysis of factors in developing a cross-border knowledge region: The case of Helsinki and Tallinn City-Regions", PhD Dissertation in Management, Institute of Social Sciences, Estonian Business School, Tallinn.

Laakso, S., E. Kostiainen, T. Kalvet and K. Velström (2012), Economic Flows Between Helsinki-Uusimaa and Tallinn-Harju Regions, Helsinki-Tallinn Transport and Planning Scenarios Project.

Lepik, K.-L. (2010), "Cross-border co-operation institutional organisation and its role in regional development", PhD Dissertation in Management, Institute of Social Sciences, Estonian Business School, Tallinn.

Maripuu, Maret (2003), Opening speech of the Helsinki-Tallinn Forum 2003, Chairperson of Tallinn City Council and Helsinki-Tallinn Euregio Management Committee.

Merk, O., O.-P. Hilmola and P. Dubarle (2012), "The competitiveness of global port-cities: The case of Helsinki, Finland”, OECD Regional Development Working Papers, No. 2012/08, OECD Publishing, http://dx.doi.org/10.1787/5k92z70x5v7g-en.

OECD (2013), Entrepreneurship at a Glance, 2013, OECD Publishing, http://dx.doi.org/10.1787/entrepreneur aag-2013-en. 
OECD (2012a), OECD Economic Surveys: Estonia 2012, OECD Publishing, http://dx.doi.org/10.1787/eco_surveys-est-2012-en.

OECD (2012b), OECD Economic Surveys: Finland 2012, OECD Publishing, http://dx.doi.org/10.1787/eco_surveys-fin-2012-en.

OECD (2011), Regions and Innovation Policy, OECD Publishing, http://dx.doi.org/10.1787/eco_surveysfin-2012-en.

Ollila, E. and J. Jõerüüt (2003), Finland and Estonia in the European Union, Prime Minister's Publications, Helsinki.

Tapaninen, U. (2012), Helsinki and Tallinn on the Move: Final Report of the H-TTransPlan Project, Tallinn-Helsinki.

Technopolis (2011), Innovation in the Baltic Sea Region, Final Report to the European Commission, Directorate-General Regional Policy, Brussels.

Technopolis (2012), "Regional innovation monitor: Baseline regional profile Etelä-Suomi”, report to the European Commission, Brussels.

Terk, E. (2012), Twin-City in the Making: Integration Scenarios for Helsinki and Tallinn Capital Regions, Tallinn University Estonian Institute for Futures Studies, Tallinn.

Uljas, H. (2012), "The effect of business on mobility between Helsinki and Tallinn”, in Tapaninen, U. (2012), Helsinki and Tallinn on the Move: Final Report of the H-TTransPlan Project, Tallinn-Helsinki. 